\title{
Nitrous oxide dynamics in low oxygen regions of the Pacific: insights from the MEMENTO database
}

\author{
L. M. Zamora ${ }^{1}$, A. Oschlies ${ }^{1}$, H. W. Bange ${ }^{1}$, K. B. Huebert ${ }^{2}$, J. D. Craig ${ }^{1}$, A. Kock ${ }^{1}$, and C. R. Löscher ${ }^{3}$ \\ ${ }^{1}$ GEOMAR Helmholtz-Zentrum für Ozeanforschung Kiel, Düsternbrooker Weg 20, 24105 Kiel, Germany \\ ${ }^{2}$ University of Hamburg Institute for Hydrobiology and Fisheries Science, Olbersweg 24, 22767 Hamburg, Germany \\ ${ }^{3}$ Institut für Allgemeine Mikrobiologie, Christian-Albrechts-Universität zu Kiel, Am Botanischen Garten 1-9, \\ 24118 Kiel, Germany
}

Correspondence to: L. M. Zamora (lzamora@geomar.de)

Received: 13 July 2012 - Published in Biogeosciences Discuss.: 1 August 2012

Revised: 31 October 2012 - Accepted: 12 November 2012 - Published: 6 December 2012

\begin{abstract}
The eastern tropical Pacific (ETP) is believed to be one of the largest marine sources of the greenhouse gas nitrous oxide $\left(\mathrm{N}_{2} \mathrm{O}\right)$. Future $\mathrm{N}_{2} \mathrm{O}$ emissions from the ETP are highly uncertain because oxygen minimum zones are expected to expand, affecting both regional production and consumption of $\mathrm{N}_{2} \mathrm{O}$. Here we assess three primary uncertainties in how $\mathrm{N}_{2} \mathrm{O}$ may respond to changing $\mathrm{O}_{2}$ levels: (1) the relationship between $\mathrm{N}_{2} \mathrm{O}$ production and $\mathrm{O}_{2}$ (is it linear or exponential at low $\mathrm{O}_{2}$ concentrations?), (2) the cutoff point at which net $\mathrm{N}_{2} \mathrm{O}$ production switches to net $\mathrm{N}_{2} \mathrm{O}$ consumption (uncertainties in this parameterisation can lead to differences in model ETP $\mathrm{N}_{2} \mathrm{O}$ concentrations of more than $20 \%$ ), and (3) the rate of net $\mathrm{N}_{2} \mathrm{O}$ consumption at low $\mathrm{O}_{2}$. Based on the MEMENTO database, which is the largest $\mathrm{N}_{2} \mathrm{O}$ dataset currently available, we find that $\mathrm{N}_{2} \mathrm{O}$ production in the ETP increases linearly rather than exponentially with decreasing $\mathrm{O}_{2}$. Additionally, net $\mathrm{N}_{2} \mathrm{O}$ consumption switches to net $\mathrm{N}_{2} \mathrm{O}$ production at $\sim 10 \mu \mathrm{MO}_{2}$, a value in line with recent studies that suggest consumption occurs on a larger scale than previously thought. $\mathrm{N}_{2} \mathrm{O}$ consumption is on the order of $0.01-1 \mathrm{mmol} \mathrm{N}_{2} \mathrm{O} \mathrm{m}^{-3} \mathrm{yr}^{-1}$ in the Peru-Chile Undercurrent. Based on these findings, it appears that recent studies substantially overestimated $\mathrm{N}_{2} \mathrm{O}$ production in the ETP. In light of expected deoxygenation and the higher than previously expected point at which net $\mathrm{N}_{2} \mathrm{O}$ production switches to consumption, there is enough uncertainty in future $\mathrm{N}_{2} \mathrm{O}$ production that even the sign of future changes is still unclear.
\end{abstract}

\section{Introduction}

The greenhouse gas nitrous oxide $\left(\mathrm{N}_{2} \mathrm{O}\right)$ is produced and consumed in low oxygen regions of the ocean such as the eastern tropical Pacific (ETP) (Naqvi et al., 2010). Because oxygen minimum zones are expected to expand under ongoing global warming (Stramma et al., 2008; Deutsch et al., 2011), future regional $\mathrm{N}_{2} \mathrm{O}$ emissions from the ETP are likely to change, perhaps even drastically (Codispoti, 2010). However, the factors that control marine $\mathrm{N}_{2} \mathrm{O}$ production and consumption respond nonlinearly to environmental changes and are not yet well understood (e.g., Bange et al., 2010). Therefore, the magnitude, and even sign, of the $\mathrm{N}_{2} \mathrm{O}$ response to ocean deoxygenation is highly uncertain.

In a simplified view, $\mathrm{N}_{2} \mathrm{O}$ concentrations within the ETP may be viewed as determined by three main factors: $\mathrm{N}_{2} \mathrm{O}$ production rates, $\mathrm{N}_{2} \mathrm{O}$ consumption rates at low $\mathrm{O}_{2}$, and the $\mathrm{O}_{2}$ value at which net $\mathrm{N}_{2} \mathrm{O}$ production switches to net $\mathrm{N}_{2} \mathrm{O}$ consumption. Currently, all of these factors have large associated uncertainties. For example, laboratory studies are at odds on whether $\mathrm{N}_{2} \mathrm{O}$ production from bacterial nitrification increases exponentially or linearly with decreasing $\mathrm{O}_{2}$ at low $\mathrm{O}_{2}$ (Goreau et al., 1980; Frame and Casciotti, 2010). An exponential vs. linear parameterisation can make a large difference in a model of marine $\mathrm{N}_{2} \mathrm{O}$ production. $\mathrm{N}_{2} \mathrm{O}$ consumption rates are even less certain than $\mathrm{N}_{2} \mathrm{O}$ production rates; laboratory and in situ data differ by more than three orders of magnitude (e.g., Castro-González and Farías, 2004; Codispoti and Christensen, 1985). It is also not clear whether there is a single $\mathrm{O}_{2}$ value that is representative of the point 
at which net $\mathrm{N}_{2} \mathrm{O}$ production switches to $\mathrm{N}_{2} \mathrm{O}$ consumption. Current estimates for this value within the ETP range from 1-20 $\mu_{\mathrm{M} \mathrm{O}_{2}}$ (e.g., Farías et al., 2009; Suntharalingam et al., 2000).

The processes that contribute to $\mathrm{N}_{2} \mathrm{O}$ concentrations in the ocean are complex and $\mathrm{O}_{2}$-dependent. In aerobic environments, $\mathrm{N}_{2} \mathrm{O}$ is primarily formed through nitrification (both via the ammonia oxidation and nitrite oxidation/nitrifierdenitrification steps) (Bange, 2008). In suboxic conditions, $\mathrm{N}_{2} \mathrm{O}$ can also be formed early in the denitrification process during nitrite reduction $\left(\mathrm{NO}_{3}^{-} \rightarrow \mathrm{NO}_{2}^{-} \rightarrow \mathrm{NO} \rightarrow \mathrm{N}_{2} \mathrm{O}\right.$ ) (Ward, 2008). However, during the last step of denitrification $\left(\mathrm{N}_{2} \mathrm{O} \rightarrow \mathrm{N}_{2}\right), \mathrm{N}_{2} \mathrm{O}$ is consumed. Whether net $\mathrm{N}_{2} \mathrm{O}$ is produced or consumed during denitrification depends on several factors. Oxygen concentrations play a large role, as denitrifiers generally produce net $\mathrm{N}_{2} \mathrm{O}$ at the high end of their $\mathrm{O}_{2}$ range (Payne et al., 1971; Knowles et al., 1981) and consume $\mathrm{N}_{2} \mathrm{O}$ in stably suboxic to anoxic environments. At complete anoxia, i.e., $\mathrm{O}_{2}=0 \mu \mathrm{M}$, denitrification does not occur at all (Bange et al., 2010). Additionally, the composition of the microbial community present plays a major role, particularly because more denitrifying microbes have the enzymatic apparatus to reduce $\mathrm{NO}_{3}^{-} \rightarrow \mathrm{NO}_{2}^{-}$than $\mathrm{N}_{2} \mathrm{O} \rightarrow \mathrm{N}_{2}$ (Zumft, 1997).

Currently, the $\mathrm{O}_{2}$ concentrations that determine which of these various processes are dominant are not clearly defined. Although nitrification is generally dominant in aerobic conditions and denitrification is generally dominant in suboxic conditions, studies indicate that these processes can co-occur within a large $\mathrm{O}_{2}$ concentration range. Ammonia-oxidizers can flourish at low $\mathrm{O}_{2}$ concentrations (Carlucci and McNally, 1969; Goreau et al., 1980), and aerobic ammonia oxidation can even be active at $\mathrm{O}_{2}$ concentrations $\sim 2 \mu \mathrm{M}$ (Kalvelage et al., 2011). Conversely, denitrification has been reported within the anaerobic interiors of marine snow in waters with $\mathrm{O}_{2}$ concentrations up to $20 \mu \mathrm{M}$ (Alldredge and Cohen, 1987; Yoshida et al., 1989). In the Peruvian OMZ, recent results indicate that anaerobic $\mathrm{NO}_{3}^{-}$reduction might be partially active at $\mathrm{O}_{2}$ levels even higher than this (Kalvelage et al., 2011). As previously mentioned, laboratory studies indicate that $\mathrm{N}_{2} \mathrm{O}$ production by ammonia-oxidizing bacteria and heterotrophic denitrifying bacteria increases nonlinearly at low $\mathrm{O}_{2}$ (Payne et al., 1971; Goreau et al., 1980; Knowles et al., 1981).

As the many processes contributing to $\mathrm{N}_{2} \mathrm{O}$ concentrations are highly complex, it is problematic that much of the data available on $\mathrm{N}_{2} \mathrm{O}$ production and consumption rates are based on simplified laboratory studies, which only assess specific organisms and conditions that are not necessarily representative of the open ocean. Archaea, for example, were only recently recognised as major contributors to nitrification (e.g., Beman et al., 2012) and marine $\mathrm{N}_{2} \mathrm{O}$ production (Santoro et al., 2011; Löscher et al., 2012). Information on their $\mathrm{N}_{2} \mathrm{O}$ production rates is still very limited. $\mathrm{N}_{2} \mathrm{O}$ production rates from anammox (Kartal et al., 2007) and nitrifier den- itrification (e.g., Charpentier et al., 2007) are also not well constrained.

The MEMENTO database, which is the largest and most recent collection of $100+$ cruises in which $\mathrm{N}_{2} \mathrm{O}$ data were sampled (Bange et al., 2009), provides the unique opportunity to re-evaluate net marine in situ $\mathrm{N}_{2} \mathrm{O}$ production and consumption rates, thus complementing laboratory studies. Here we quantitatively investigate the dynamics of marine $\mathrm{N}_{2} \mathrm{O}$ in the eastern tropical Pacific, one of the ocean's largest suboxic zones. Our goal is to provide a set of guidelines for ocean $\mathrm{N}_{2} \mathrm{O}$ models of the ETP. We estimate subsurface $\mathrm{N}_{2} \mathrm{O}$ production rates at low $\mathrm{O}_{2}$ concentrations in order to determine whether rates increase exponentially as previously predicted. We also examine in situ $\mathrm{N}_{2} \mathrm{O}$ consumption rates in the ETP and estimate the $\mathrm{O}_{2}$ concentration at which net $\mathrm{N}_{2} \mathrm{O}$ production switches to net $\mathrm{N}_{2} \mathrm{O}$ consumption. Finally, we test the sensitivity of $\mathrm{N}_{2} \mathrm{O}$ distributions simulated by a global ocean model to uncertainties in these values. By geochemically evaluating the dynamics of net $\mathrm{N}_{2} \mathrm{O}$ production and consumption, we constrain some of the uncertainties derived from the complex dynamics of individual microbial processes in the ocean.

\section{Methods}

\subsection{MEMENTO observations}

$\mathrm{N}_{2} \mathrm{O}$ observations were obtained from a preliminary version of the MEMENTO database (version as of September 2011, see Fig. 2) currently in development (Bange et al., 2009). The version of the Pacific MEMENTO database used here includes 10 subsurface datasets gathered between 1976-2009 (station locations are shown in Fig. 2). Most of these $\mathrm{N}_{2} \mathrm{O}$ datasets have been comprehensively described previously (Cohen and Gordon, 1978; Pierotti and Rasmussen, 1980; Friederich et al., 1992; Dore and Karl, 1996; Dore et al., 1998; Popp et al., 2002; Nevison et al., 2003; Charpentier et al., 2007; Farías et al., 2007; Ryabenko et al., 2012), with the exception of two cruises in the ETP (Kock and Löscher, unpublished data; Bange, unpublished data). $\mathrm{N}_{2} \mathrm{O}$ values for all cruises were obtained by gas chromatography coupled with electron capture detectors. Precision for $\mathrm{N}_{2} \mathrm{O}$ measurements for all datasets was $<3.4 \%$. For most datasets, $\mathrm{O}_{2}$ was determined by modified Winkler method (the exception being that of Charpentier et al. (2007), where $\mathrm{O}_{2}$ was determined by CTD measurements calibrated with the Winkler method). Measurements of $\mathrm{NO}_{2}^{-}, \mathrm{NO}_{3}^{-}$and $\mathrm{PO}_{4}^{3-}$ were determined spectrophotometrically. Note that only 5 of the 11 datasets used in this study include $\mathrm{NO}_{2}^{-}$measurements (see Fig. 7).

Salinity/temperature were obtained from CTD casts, with the exception of Pierotti and Rasmussen (1980) where temperature was measured by expendable bathythermograph and salinity was not measured. For this cruise, salinity was interpolated from the nearest World Ocean Atlas 2009 data (and 
was used only to calculate the $\mathrm{N}_{2} \mathrm{O}_{\text {eq }}$ value and apparent oxygen utilisation of the water mass as presented in Sect. 2.2). Because the data from which the WOA 2009 salinity data were gathered were not sampled in exactly the same locations or times as the Pierotti and Rasmussen (1980) data, this generates some very minor uncertainty in our interpretation of $\mathrm{N}_{2} \mathrm{O}_{\mathrm{xs}} / \mathrm{AOU}$ ratios and $\mathrm{N}_{2} \mathrm{OPR}$ values. Even assuming a major salinity difference of one salinity unit, this uncertainty is expected to be $<1 \%$ of the values of the ratio and rate, respectively.

We additionally instituted quality control measures to ensure that the data entered into the MEMENTO dataset were entered correctly. This included checking whether $\mathrm{N}_{2} \mathrm{O}$ concentrations and other seawater components/properties were consistent with expected values from surrounding cruises and checking whether surface values were consistent with atmospheric $\mathrm{N}_{2} \mathrm{O}$ concentrations expected for the year of sampling (to check for calibration issues). Data with quality flags were not included in the analysis. Although the data presented here represent a preliminary version of the MEMENTO database (which is still in development), these data used in this paper can be requested from H. Bange (hbange@geomar.de).

\subsection{Calculating $\mathrm{N}_{2} \mathrm{O}$ production rates}

In order to correctly estimate $\mathrm{N}_{2} \mathrm{O}$ production rates, it is important to distinguish the relative fractions of $\mathrm{N}_{2} \mathrm{O}$ formed by in situ (i.e., biological) processes and $\mathrm{N}_{2} \mathrm{O}$ originating from air-sea gas exchange (from when the water mass was in contact with the atmosphere), which itself has displayed increasing $\mathrm{N}_{2} \mathrm{O}$ concentrations since preindustrial times. In the past, salinity- and temperature-based solubility calculations were typically used: the excess $\mathrm{N}_{2} \mathrm{O}$ remaining after accounting for air-sea gas exchange (i.e., the "biotic" $\mathrm{N}_{2} \mathrm{O}$ fraction) was labelled $\Delta \mathrm{N}_{2} \mathrm{O}$ (e.g., Yoshinari, 1976). Recently, water mass age estimates have been incorporated in abiotic $\mathrm{N}_{2} \mathrm{O}$ calculations in order to address both water mass mixing and increasing atmospheric $\mathrm{N}_{2} \mathrm{O}$ concentrations over the past $150 \mathrm{yr}$ (Freing et al., 2009).

Here, we account for historic increases in atmospheric $\mathrm{N}_{2} \mathrm{O}$ using the transit time distribution (TTD) method described in Freing et al. (2009) and Waugh et al. (2003) (see the Appendix for a more detailed description of the TTD method as applied here). Similarly to Waugh et al. (2003), we assume that a water parcel is a mixture of water with various ages, and that the density distribution of these ages can be described using an Inverse Gaussian distribution of the form:

$G(t)=\sqrt{\frac{\Gamma^{3}}{\pi 4 \Delta^{2} t^{3}}} \exp \left(\frac{-\Gamma(t-\Gamma)^{2}}{4 \Delta^{2} t}\right)$

where $t$ is time since ventilation at the ocean surface and $\Gamma$ (mean age) and $\Delta$ (width) are the first and second moments of the distribution.
As in Freing et al. (2009), we estimate $\mathrm{N}_{2} \mathrm{O}_{\text {eq }}$ (the $\mathrm{N}_{2} \mathrm{O}$ concentration derived from equilibrium with atmospheric $\mathrm{N}_{2} \mathrm{O}$ when the water was last in contact with the atmosphere) as follows:

$$
\left[\mathrm{N}_{2} \mathrm{O}\right]_{\mathrm{eq}}^{\mathrm{TTD}}(t)=\int_{0}^{\infty} H_{T, S} X_{\mathrm{N}_{2} \mathrm{O}}\left(t-t^{\prime}\right) G\left(t^{\prime}\right) \mathrm{d} t^{\prime},
$$

where $H_{T, S}$ is solubility (Weiss and Price, 1980) and $X_{\mathrm{N}_{2} \mathrm{O}}$ is the atmospheric dry mole fraction of $\mathrm{N}_{2} \mathrm{O}$ at the estimated time of ventilation. For water masses ventilated before 1750 , we assumed that the $X_{\mathrm{N}_{2} \mathrm{O}}$ concentration was $270 \mathrm{ppb}$ (Denman et al., 2007). After 1750 , atmospheric $\mathrm{N}_{2} \mathrm{O}$ dry mole fractions were assumed to increase according to Holland et al. (2005).

The TTD method cannot be tested with in situ observations since it is impossible to know the actual $\mathrm{N}_{2} \mathrm{O}_{\text {eq }}$ values with certainty. Therefore, we tested the validity of the TTD method by comparing modelled $\mathrm{N}_{2} \mathrm{O}_{\text {eq }}$ with estimated $\mathrm{N}_{2} \mathrm{O}_{\text {eq }}$. Modelled $\mathrm{N}_{2} \mathrm{O}_{\text {eq }}$ was obtained from our UVic-ESCM model by turning biological $\mathrm{N}_{2} \mathrm{O}$ consumption and production off, so that the only factor affecting modelled $\mathrm{N}_{2} \mathrm{O}$ concentrations was air-sea gas exchange, atmospheric $\mathrm{N}_{2} \mathrm{O}$, and physiochemical properties of the water affecting this exchange (salinity, temperature, etc.). We then compared modelled $\mathrm{N}_{2} \mathrm{O}_{\text {eq }}$ with estimated $\mathrm{N}_{2} \mathrm{O}_{\text {eq }}$, whereby atmospheric $\mathrm{N}_{2} \mathrm{O}$ was estimated by three methods: (1) the current model year (which would correspond to sample date if this method were used for observational data, as in Elkins et al. (1978), (2) atmospheric $\mathrm{N}_{2} \mathrm{O}$ as estimated by modelled pCFC-12 age (which was calculated by matching observed pCFC-12 concentrations to the historic pCFC- 12 concentration that would arise given the salinity and temperature of that water mass using solubility calculations from Warner and Weiss, 1985), and (3) the TTD age based on modelled pCFC-12 ages. This test was done for the year 2000 of the UVic-ESCM simulation (described in Sect. 2.1).

Results, shown in Fig. 1, indicate that the TTD method works well in the modelled ETP, with only a $3 \%$ error between the model actual and model TTD estimated $\mathrm{N}_{2} \mathrm{O}_{\text {eq }}$ values, providing a modest improvement in the estimation of the biotic $\mathrm{N}_{2} \mathrm{O}$ component in comparison to methods used previously, even when a conservative $\Delta / \Gamma$ ratio of 1 is used (Fig. 1). For more information on $\Delta / \Gamma$ ratios relevant to this region, see the Appendix.

Once $\mathrm{N}_{2} \mathrm{O}_{\text {eq }}$ values were calculated, the "biotic" $\mathrm{N}_{2} \mathrm{O}$ portion of the total $\mathrm{N}_{2} \mathrm{O}$ signal $\left(\mathrm{N}_{2} \mathrm{O}_{\mathrm{xs}}\right)$ was calculated as the difference between in situ $\mathrm{N}_{2} \mathrm{O}$ concentrations and $\mathrm{N}_{2} \mathrm{O}_{\mathrm{eq}}$ (Freing et al., 2009):

$$
\mathrm{N}_{2} \mathrm{O}_{\text {xs }}=\mathrm{N}_{2} \mathrm{O}_{\text {in situ }}-\mathrm{N}_{2} \mathrm{O}_{\text {eq }}
$$

The TTD method also enables the calculation of water mass mean ages, thereby allowing a more accurate estimate 


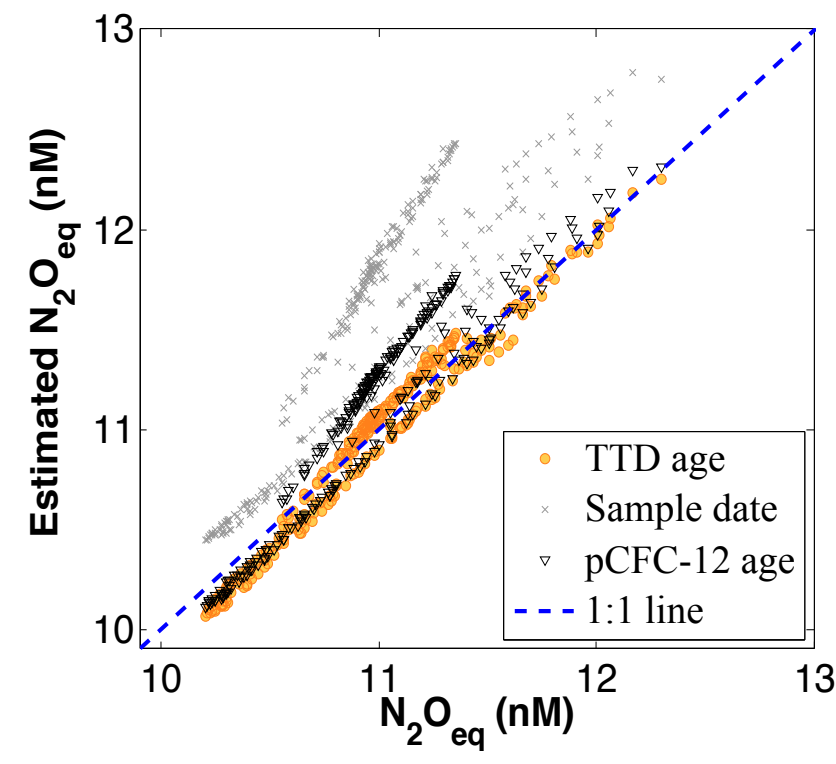

Fig. 1. The relationship between explicit model $\mathrm{N}_{2} \mathrm{O}_{\text {eq }}$ values and $\mathrm{N}_{2} \mathrm{O}_{\text {eq }}$ estimated from (1) the sampling date atmospheric $\mathrm{N}_{2} \mathrm{O}$ values (in this case historical atmospheric $\mathrm{N}_{2} \mathrm{O}$ variations are not accounted for) (gray crosses, $R^{2}=0.42$ ), (2) CFC-12 ages (black triangles, $R^{2}=0.85$ ), and (3) mean ages derived from the transit time distribution (TTD) method conservatively assuming "high" mixing (a $\Delta / \Gamma$ ratio of 1 ) at each site (orange circles, $R^{2}=0.96$ ). The $R^{2}$ values indicate how well each dataset describes the $1: 1$ line shown above (blue dashed line) using the sum of squares method. Data were obtained from the region between $10^{\circ} \mathrm{N}-23.5^{\circ} \mathrm{S}, 200-290^{\circ} \mathrm{E}$, and within the $26.25-26.75 \sigma_{\theta}$ density layer.

of the $\mathrm{N}_{2} \mathrm{O}$ production rate $\left(\mathrm{N}_{2} \mathrm{OPR}\right)$ :

$\mathrm{N}_{2} \mathrm{OPR}=\frac{\mathrm{N}_{2} \mathrm{O}_{\mathrm{xs}}}{\Gamma}$

where $\Gamma$ is the TTD calculated mean age of the water sample and $\mathrm{N}_{2} \mathrm{OPR}$ is the average production rate the water parcel has experienced since the last contact with the atmosphere (as opposed to the instantaneous rate).

In order to base our analysis on reliable data, we excluded some samples using the criteria discussed below. First, because gas exchange with the atmosphere and temperaturedriven solubility changes create large uncertainties in the relative portion of $\mathrm{N}_{2} \mathrm{O}$ with abiotic $\left(\mathrm{N}_{2} \mathrm{O}_{\text {eq }}\right)$ and biotic $\left(\mathrm{N}_{2} \mathrm{O}_{\mathrm{xs}}\right)$ origins, all values from the upper $150 \mathrm{~m}$ were excluded. Second, we excluded all data with TTD mean age of $\leq 15 \mathrm{yr}$, since the oldest TTD mean age for which a negative $\mathrm{N}_{2} \mathrm{O}_{x s}$ value was found was at $15 \mathrm{yr}$, indicating that samples with ages younger than $15 \mathrm{yr}$ still had $\mathrm{N}_{2} \mathrm{O}_{\mathrm{xs}}$ values that were too low to reliably distinguish from $\mathrm{N}_{2} \mathrm{O}_{\text {eq }}$ values. Excluding the samples with TTD ages $<15 \mathrm{yr}$ effectively also eliminated all samples with AOU values of $<18 \mu \mathrm{M}$ and $\mathrm{O}_{2}$ saturations of $>95 \%$, thus also excluding data where $\mathrm{N}_{2} \mathrm{O}_{x s} / A O U$ ratios (used in Sect. 3.1) would have been highly skewed by low AOU values in the denominator. Note: in a similar anal-

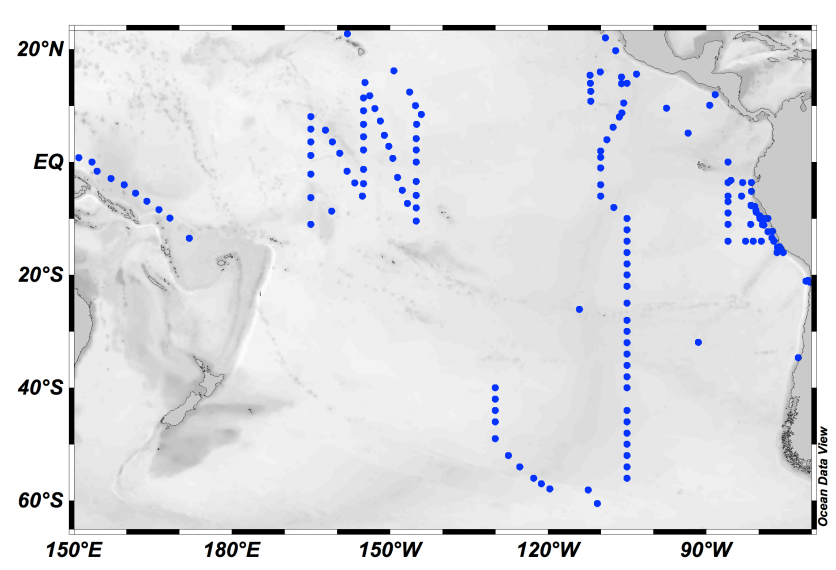

Fig. 2. Locations of Pacific sub-surface profiles contained in the MEMENTO dataset and used in this study.

ysis that did not apply TTD methods, Nevison et al. (2003) dealt with this problem by excluding all data where AOU was $<50 \mu \mathrm{M}$. Third, to ensure data quality for the TTD determinations, we also removed all data with quality flags and samples with CFC-12 concentrations below $0.01 \mathrm{pM}$ (a typical detection limit for CFC-12), and when relevant, with tritium values below $0.08 \mathrm{TU}$. Because we only examined waters with detectable CFC-12 values, most of the data used here were located in the 150-2000 m depth range. This depth range includes the region containing highest $\mathrm{N}_{2} \mathrm{O}$ values (Fig. 3).

For the analysis of $\mathrm{N}_{2} \mathrm{O}$ production rates presented in Sect. 3.1, we separated the data into two bins: one where $\mathrm{O}_{2}$ was $>10 \mu \mathrm{M}$ and another where $\mathrm{O}_{2}$ was $<10 \mu \mathrm{M}$. The former was used for analysis of the $\mathrm{N}_{2} \mathrm{O}$ production rate and the latter for $\mathrm{N}_{2} \mathrm{O}$ consumption rate. A concentration of $10 \mathrm{MMO}_{2}$ is the highest oxygen value where we believe $\mathrm{N}_{2} \mathrm{O}$ consumption could begin (see Sect. 3.2). Based on recent data presented by Cornejo and Farías (2012), a cutoff point of $10 \mu \mathrm{MO}_{2}$ is a slightly conservative value (their data indicate that $\mathrm{N}_{2} \mathrm{O}$ consumption in the ETSP starts at $8 \mu \mathrm{M}$ $\mathrm{O}_{2}$ ). Because mixing may spread the signal of waters affected by $\mathrm{N}_{2} \mathrm{O}$ consumption into nearby waters, we additionally excluded all samples where nitrite $\left(\mathrm{NO}_{2}^{-}\right)$concentrations were $>0.1$ (i.e., above detection limits). Nitrite is an intermediate of denitrification, among other processes, and it is an indicator of likely $\mathrm{N}_{2} \mathrm{O}$ consumption (Cornejo and Farías, 2012) in the region below the upper (primary) $\mathrm{NO}_{2}^{-}$ maximum $(\sim 150 \mathrm{~m})$ (Cline and Richards, 1972; Cohen and Gordon, 1978). As we excluded samples in the upper $150 \mathrm{~m}$, there is minimal impact of the upper $\mathrm{NO}_{2}^{-}$maximum on our analysis. 


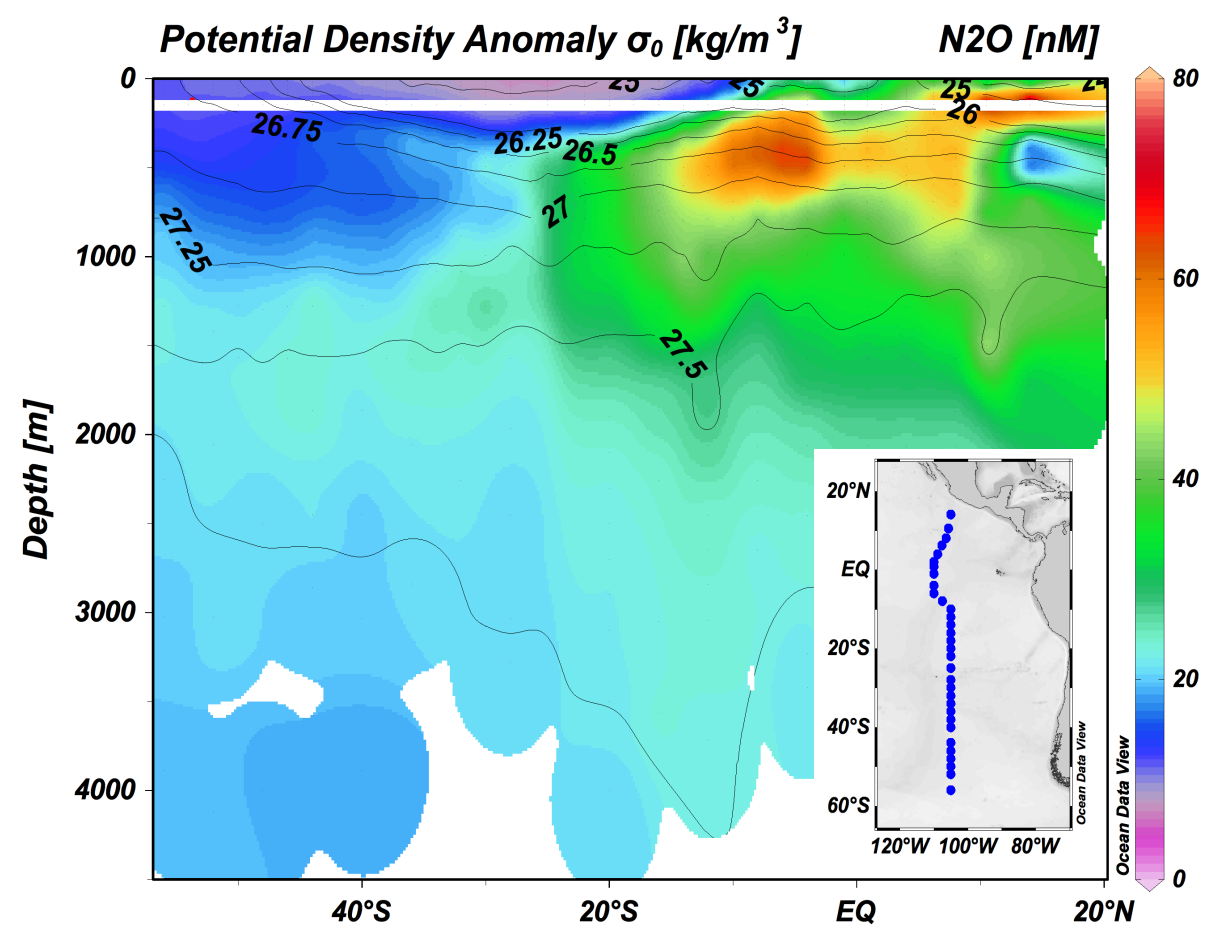

Fig. 3. Section of $\mathrm{N}_{2} \mathrm{O}(\mathrm{nM})$ concentrations from the RITS89 cruise. In the tropical and subtropical Eastern Pacific, the bulk of $\mathrm{N}_{2} \mathrm{O}$ is located in the upper $800 \mathrm{~m}$. The white line indicates $150 \mathrm{~m}$ depth (above which data were excluded for reasons discussed in the text).

\subsection{Calculating $\mathrm{N}_{2} \mathrm{O}$ consumption rates}

The $\mathrm{N}_{2} \mathrm{O}$ consumption rate is calculated using Eq. (5) based on the method used by Codispoti and Christensen (1985):

$\mathrm{N}_{2} \mathrm{O}$ consumption rate $\left(\mathrm{mmol} \mathrm{N}_{2} \mathrm{O} \mathrm{m} \mathrm{m}^{-3} \mathrm{yr}^{-1}\right)$

$=\frac{\text { loss of } \mathrm{N}_{2} \mathrm{O}\left(\mathrm{mmol} \mathrm{m}^{-3}\right)}{\text { residence time }(\mathrm{yr})}$

To estimate net $\mathrm{N}_{2} \mathrm{O}$ consumption rates while minimising the effects of local variability, we examined a region over $\sim 100000 \mathrm{~km}^{2}$ from $\sim 6^{\circ} \mathrm{S}$ to $16^{\circ} \mathrm{S}$ and between the 26.3 and $26.5 \sigma_{\theta}$ density layer (Fig. 4c). This region, which is located along the Peru-Chile undercurrent (PCUC), was selected because altimeter (Strub et al., 1995; Pizarro et al., 2002) and current-meter data (Shaffer et al., 1995; Czeschel et al., 2011) indicate a predominantly unidirectional flow along the coast, allowing a comparison in water mass chemical changes along the direction of water mass flow. Additionally, denitrification-driven $\mathrm{N}_{2} \mathrm{O}$ consumption is likely occurring in this region based on decreases in $\mathrm{N}_{2} \mathrm{O}$ and $\mathrm{N}^{*}$ concentrations $\left(\mathrm{N}^{*}\right.$ is the deviation in inorganic nutrients from Redfield ratios, or $\left.\left(\mathrm{NO}_{3}^{-}+\mathrm{NO}_{2}^{-}\right)-16 \times \mathrm{PO}_{4}^{3-}\right)$, an increase in $\mathrm{NO}_{2}^{-}$concentrations and uniformly low oxygen concentrations $(<10 \mu \mathrm{M})$ (Fig. 4). Samples from this region were collected in February 1985 (Friederich et al., 1992) and in February 2009 (Kock and Löscher, unpublished data). $\mathrm{N}_{2} \mathrm{O}$ loss is calculated based on the reduction in $\mathrm{N}_{2} \mathrm{O}$ concentrations along the direction of water mass flow (Fig. 4c) and water residence time is calculated based on timescale of water mass flow from model flow velocities (see Sect. 3.2).

For the model sensitivity analyses, we used the University of Victoria Earth System Climate Model (UVic-ESCM) version 2.9 as modified by Keller et al. (2012). The resolution of this model is $3.6^{\circ}$ longitude by $1.8^{\circ}$ latitude with 19 vertical levels. Historic atmospheric $\mathrm{N}_{2} \mathrm{O}$ concentrations up to the year 2008 were obtained from Holland et al. (2005). Marine $\mathrm{N}_{2} \mathrm{O}$ production rate per $\mathrm{O}_{2}$ molecule consumed $\left(\mathrm{nmol} \mu \mathrm{mol}^{-1}\right)$ was parameterised as a linear function of $\mathrm{O}_{2}$ concentration: $1.69 \times 10^{-4}-4.8 \times 10^{-7} \times \mathrm{O}_{2}$ $\left(\mathrm{mol} \mathrm{m}^{-3}\right)$. If $\mathrm{O}_{2}$ concentrations fell below a threshold value of $10 \mu \mathrm{mol}, \mathrm{N}_{2} \mathrm{O}$ consumption began (either at 0.01, 0.1, and $1 \mathrm{mmol} \mathrm{m}^{-3} \mathrm{yr}^{-1}$, see Sect. 3.2). To measure sensitivity to the threshold value at which net $\mathrm{N}_{2} \mathrm{O}$ production switches to net $\mathrm{N}_{2} \mathrm{O}$ consumption, values of $1,4,10$, and $15 \mu \mathrm{M} \mathrm{O}_{2}$ were also tested (see Sect. 3.3). For these sensitivity analyses, $\mathrm{N}_{2} \mathrm{O}$ consumption rate was assumed to be $0.1 \mathrm{mmol} \mathrm{N}_{2} \mathrm{O} \mathrm{m}^{-3} \mathrm{yr}^{-1}$. $\mathrm{N}_{2} \mathrm{O}$ production and consumption were assumed to be independent of temperature or depth. See Sects. 3.1-3.4 for details on why these parameterisations were selected and Appendix B for further model description.

For improved accuracy of current velocities in the PeruChile Undercurrent (Sect. 3.3), we used a higher resolution version of the global ocean model (the Geophysical Fluid Dynamics Laboratory Modular Ocean Model 4, or MOM4) (Zamora et al., 2010). The MOM4 model was only used to calculate velocity fields; the sensitivity analyses and 

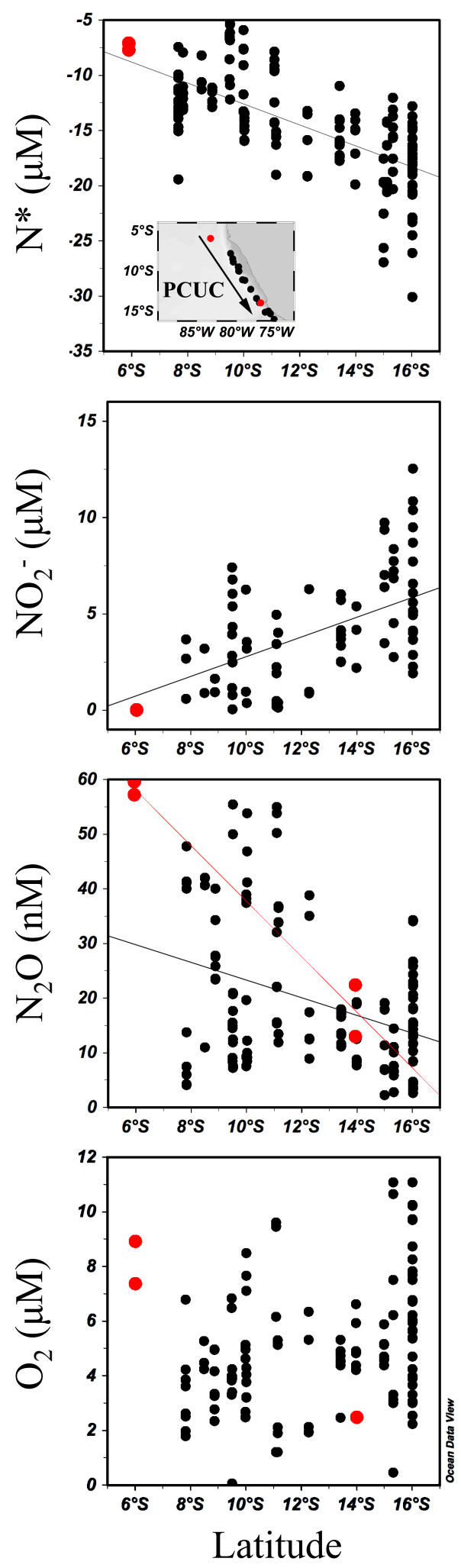

Fig. 4. Concentrations of $\mathrm{NO}_{2}^{-}, \mathrm{O}_{2}, \mathrm{~N}_{2} \mathrm{O}$, and $\mathrm{N}^{*}$ in the Peru-Chile Undercurrent (PCUC) in February 1985 (black) and February 2009 (red) between 26.3-26.5 $\sigma_{\theta}$. Black and red lines are the least squares line for 1985 and 2009 data, respectively. The insert shows the station locations and the direction of flow for the PCUC. derivation of biogeochemical distributions (e.g., $\mathrm{N}_{2} \mathrm{O}, \mathrm{O}_{2}$ ) were derived separately and solely from the UVic-ESCM discussed previously. This version of the MOM4 model had a $1^{\circ}$ longitude by $1^{\circ}$ latitude resolution with 50 vertical layers.

\section{Results and discussion}

\subsection{Subsurface $\mathrm{N}_{2} \mathrm{O}$ production rates}

The MEMENTO data show a slight linear increase in the $\mathrm{N}_{2} \mathrm{O}_{\mathrm{xS}}$ /AOU ratio (Fig. 5) with decreasing oxygen (note that expected spurious relationships between $\mathrm{N}_{2} \mathrm{O}_{\mathrm{xs}} / \mathrm{AOU}$ and $\mathrm{O}_{2}$, plotted in Fig. 5, have been ruled out as the cause for the observed pattern). Based on Fig. 5, for $\mathrm{O}_{2}$ levels above $10 \mu \mathrm{M}$, observed subsurface $\mathrm{N}_{2} \mathrm{O}_{\mathrm{xs}}$ /AOU ratios (in nmol $\mathrm{N}_{2} \mathrm{O} / \mu$ mol $\mathrm{O}_{2}$ ) can be described by a linear relationship equaling $0.169-0.000243 \times \mathrm{O}_{2}(\mu \mathrm{M})$, with a median ratio of 0.131 . Observed $\mathrm{N}_{2} \mathrm{O}_{\mathrm{xs}}$ results from the average $\mathrm{N}_{2} \mathrm{O}$ production as the water mass transitioned from saturated $\mathrm{O}_{2}$ to observed $\mathrm{O}_{2}$. Therefore, the relationship between $\mathrm{N}_{2} \mathrm{O}$ production and $\mathrm{O}_{2}$ consumption corresponds to the relationship between observed $\mathrm{N}_{2} \mathrm{O}_{\mathrm{xs}}$ and the mean AOU during this transition. In this case the relationship is linear, and so mean $\mathrm{AOU}$ is equal to $\left(\mathrm{AOU}_{\text {observed }}+\mathrm{AOU}_{\text {initial }}\right) / 2=(\mathrm{AOU}+0) / 2=0.5 \mathrm{AOU}$. Thus, $\mathrm{N}_{2} \mathrm{O}$ production derived from $\mathrm{N}_{2} \mathrm{O}_{\mathrm{xs}} / \mathrm{AOU}$ ratios is best described by a slope of two times the observed slope with respect to $\mathrm{O}_{2}$ (in this case, $0.000486 \mathrm{nmol}$ $\mathrm{N}_{2} \mathrm{O} / \mu \mathrm{molO} \mathrm{O}_{2}$ ). It is important to note that while this relationship holds within the conditions that the data cover, we cannot extrapolate this relationship to other conditions (i.e., temperature, $\mathrm{O}_{2}$, etc.) not included in this dataset.

In contrast to our findings, laboratory experiments conducted by Goreau et al. (1980) previously indicated that the yield of $\mathrm{N}_{2} \mathrm{O}$ from bacterial nitrification has a strong exponential increase with decreasing $\mathrm{O}_{2}$, causing some later studies to parameterise $\mathrm{N}_{2} \mathrm{O}$ production as exponentially related to $\mathrm{O}_{2}$ concentrations (Suntharalingam et al., 2000, 2012; Nevison et al., 2003). However, more recent laboratory work indicates that bacterial nitrification $\mathrm{N}_{2} \mathrm{O}$ production rates only exhibit exponential behaviour under conditions rarely observed in the real ocean (i.e., cell densities $>10^{6}$ cells ml ${ }^{-1}$ and $<0.5 \% \mathrm{O}_{2}$ saturations; Frame and Casciotti, 2010). Archaeal $\mathrm{N}_{2} \mathrm{O}$ production rates also appear to increase as $\mathrm{O}_{2}$ decreases (Löscher et al., 2012), although the archaeal $\mathrm{N}_{2} \mathrm{O}$ production at very low $\mathrm{O}_{2}(<50 \mu \mathrm{M})$ has not been described to our knowledge. As an exponential vs. linear $\mathrm{N}_{2} \mathrm{O}$ production parameterisation would be expected to produce large differences in model $\mathrm{N}_{2} \mathrm{O}$ concentrations, $\mathrm{N}_{2} \mathrm{O}$ production at low $\mathrm{O}_{2}$ concentrations has to date been a large uncertainty in models, especially near oxygen minimum zones.

Nevison et al. (2003), who examined the relationship between $\Delta \mathrm{N}_{2} \mathrm{O} / \mathrm{AOU}$ ratios and $\mathrm{O}_{2}$ concentrations using a 


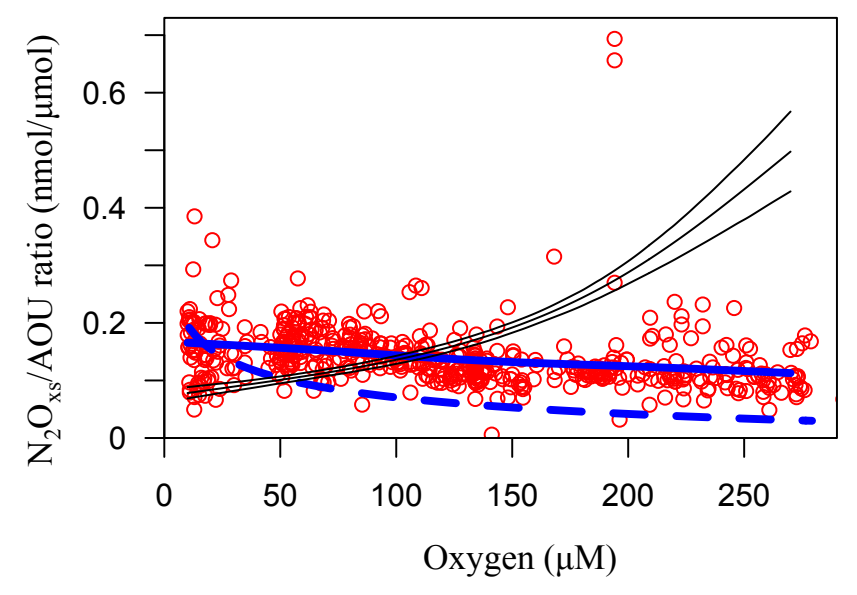

Fig. 5. $\mathrm{N}_{2} \mathrm{O}_{\mathrm{xs}} / A O U$ ratios vs. $\mathrm{O}_{2}$ concentrations for MEMENTO profiles shown in Fig. 2. The thick, solid blue line is a spline (cubic smoothing) of the best fit for the data, with individual data shown in red. The dashed blue line indicates the expected cumulative production rate if production were to follow the Goreau et al. (1980) data as parameterised in Nevison et al. (2003), their Eq. (6). Thin black lines are the spurious relationship (cubic smoothing splines for the median and $95 \%$ confidence interval) that would be expected if the data were randomised. As spurious correlations have the opposite signal as the data, the relationship between $\mathrm{N}_{2} \mathrm{O}_{\mathrm{xs}} /$ AOU vs. $\mathrm{O}_{2}$ observed is non-random.

dataset similar to the MEMENTO dataset, obtained similar distributions to that shown in Fig. 5. Thus, the use of $\Delta \mathrm{N}_{2} \mathrm{O}$ in Nevison et al. (2003) and our use of $\mathrm{N}_{2} \mathrm{O}_{\mathrm{xs}}$ as approximations for biotic $\mathrm{N}_{2} \mathrm{O}$ did not appear to cause large differences in trends in biotic $\mathrm{N}_{2} \mathrm{O} / \mathrm{AOU}$ ratios. Although Nevison et al. (2003) suggested that models use an exponential parameterisation based on the Goreau et al. (1980) laboratory study, their data also showed no clear evidence for a strongly nonlinear exponential relationship between net $\mathrm{N}_{2} \mathrm{O}$ production and $\mathrm{O}_{2}$ concentrations, even in the $\mathrm{O}_{2}$ ranges where $\mathrm{N}_{2} \mathrm{O}$ exponential increases would be expected according to the Goreau et al. (1980) data.

For comparison in Fig. 5, we plot the expected exponential relationship between $\mathrm{N}_{2} \mathrm{O}_{\mathrm{xs}} / \mathrm{AOU}$ ratio and $\mathrm{O}_{2}$ based on Goreau et al. (1980) as defined in Eq. (6) of Nevison et al. (2003). Nevison et al. (2003) hypothesised that the lack of observed in situ exponential behaviour might have been due to mixing with $\mathrm{N}_{2} \mathrm{O}$-depleted waters from OMZs, a hypothesis that is supported by modelling work by Jin and Gruber (2003), who were able to reproduce observed $\mathrm{N}_{2} \mathrm{O}$ vs. $\mathrm{O}_{2}$ concentrations in the ETP using a model that included an exponential function at low $\mathrm{O}_{2}$ levels. In addition to mixing, it is also possible that the lack of observed exponential behaviour could be explained by a smaller than previously expected volume of water in which conditions exist where exponential behaviour would be observable (as the data of Frame and Casciotti, 2010, seem to suggest). It is also worthwhile to emphasise that the Goreau et al. (1980) study was limited to bacterial nitrification. Therefore, it is possible that $\mathrm{N}_{2} \mathrm{O}$ production from other sources, such as denitrification (e.g., Farías et al., 2009) or archaeal nitrification, is larger than previously thought and that these sources do not exponentially increase as $\mathrm{O}_{2}$ declines (although laboratory data do suggest some sort of increase in yields of $\mathrm{N}_{2} \mathrm{O}$ at low $\mathrm{O}_{2}$ levels from these processes; Payne et al., 1971; Knowles et al., 1981; Löscher et al., 2012). Independent of mechanism, it appears that the best description of net $\mathrm{N}_{2} \mathrm{O}$ production in the ETP is a linear or nearly linear function of decreasing $\mathrm{O}_{2}$ (as opposed to the severely nonlinear exponential function suggested by the Goreau et al. (1980) laboratory study). Note, however, that substantial uncertainties exist for the role particularly of mixing in determining the observations shown in Fig. 5.

Note that there is relatively high variability in the $\mathrm{N}_{2} \mathrm{O}_{\mathrm{xs}} /$ AOU ratios shown in Fig. 5. The MEMENTO median ratio of $0.131 \mathrm{nmol} \mathrm{N}_{2} \mathrm{O}_{\mathrm{xs}} / \mu \mathrm{mol} \mathrm{AOU}$ falls within the range of other studies in the eastern Pacific $(0.08-0.22)$ based on linear slope calculations (Elkins et al., 1978; Cohen and Gordon, 1979; Cline et al., 1987; Butler et al., 1989; Nevison et al., 2003; Farías et al., 2007; Ryabenko et al., 2012). It is possible that some of the relatively high variability in $\mathrm{N}_{2} \mathrm{O}$ produced per $\mathrm{O}_{2}$ molecule consumed observed in Fig. 5 is due to mixing of water masses (Jin and Gruber, 2003), the variable abundance of bacterial and archaeal nitrifiers (Beman et al., 2012), or composition and availability of organic matter (Nevison et al., 2003). Also note that although we proxy $\mathrm{N}_{2} \mathrm{O}$ production via the $\mathrm{N}_{2} \mathrm{O}_{\mathrm{xs}} / \mathrm{AOU}$ ratio, in reality the production would ideally be described by the relationship between $\mathrm{N}_{2} \mathrm{O}$ production and $\mathrm{NH}_{4}^{+}$and $\mathrm{NO}_{3}^{-}$loss, because the $\mathrm{N}_{2} \mathrm{O}_{\text {xs }} / \mathrm{AOU}$ ratio masks changes in the relative contribution of nitrification and denitrification at a given oxygen concentration. Different relative contributions of these multiple processes may contribute to the scatter shown in Fig. 5 as well. Note, however, that the MEMENTO data span a wide range of in situ temperature, mixing, geographic and temporal conditions. Thus, it seems unlikely that future changes in the relative contribution of nitrification and denitrification will cause noticeable change in $\mathrm{N}_{2} \mathrm{O}$ production from its current relationship as indicated in Fig. 5.

\section{2 $\mathrm{N}_{2} \mathrm{O}$ consumption rates}

Here we focus on the Peru-Chile undercurrent (PCUC) region from $\sim 6^{\circ} \mathrm{S}$ to $16^{\circ} \mathrm{S}$ and between the 26.3 and $26.5 \sigma_{\theta}$ density layer (Fig. 4). As shown in Fig. 4, $\mathrm{N}_{2} \mathrm{O}$ consumption is likely occurring in this region based on a decrease in $\mathrm{N}_{2} \mathrm{O}$ concentrations of $0.0264-0.0407 \mathrm{mmol} \mathrm{m}^{-3}$, a $13 \mu \mathrm{M}$ decrease in $\mathrm{N}^{*}$, and a $5 \mu \mathrm{M}$ increase in $\mathrm{NO}_{2}^{-}$concentrations and uniformly low oxygen concentrations $(<10 \mu \mathrm{M})$ (see Sect. 3.3).

From Eq. (5), an assumed residence time of $0.32 \mathrm{yr}$ (Table 1), and a $\mathrm{N}_{2} \mathrm{O}$ loss of $0.0407 \mathrm{mmol} \mathrm{m}^{-3}$ (Table 1), we calculate a net $\mathrm{N}_{2} \mathrm{O}$ consumption rate of 
0.01-1 $\mathrm{mmol} \mathrm{N}_{2} \mathrm{O} \mathrm{m}^{-3} \mathrm{yr}^{-1}$ within the 26.3 and $26.5 \sigma_{\theta}$ density layer of focus. There is a relatively large uncertainty of one order of magnitude in the above rate due to uncertainties in water mass residence time (Table 1) as well as to uncertainties in flow of the PCUC caused by eddies (e.g., Czeschel et al., 2011; Altabet et al., 2012).

The PCUC calculated $\mathrm{N}_{2} \mathrm{O}$ consumption rate of $0.01-$ $1 \mathrm{mmol} \mathrm{N}_{2} \mathrm{O} \mathrm{m}^{-3} \mathrm{yr}^{-1}$ is on the low-end of laboratory $\mathrm{N}_{2} \mathrm{O}$ consumption rate measurements in ETP samples, which average from $1-1172 \mathrm{mmol} \mathrm{m}^{-3} \mathrm{yr}^{-1}$ (Castro-González and Farías 2004; Farías et al., 2009). In contrast, the PCUC consumption rates are on the high-end of most geochemical estimates of net $\mathrm{N}_{2} \mathrm{O}$ consumption rates, which range from 0.0005-0.012 $\mathrm{mmol} \mathrm{N}_{2} \mathrm{O} \mathrm{m}^{-3} \mathrm{yr}^{-1}$ (Yamagishi et al., 2007) to $0.068 \mathrm{mmol} \mathrm{N}_{2} \mathrm{O} \mathrm{m}^{-3} \mathrm{yr}^{-1}$ (Codispoti and Christensen, 1985).

Some of the discrepancies between previously published laboratory and geochemical estimates of $\mathrm{N}_{2} \mathrm{O}$ consumption may be due to local fluctuations in consumption rates; one laboratory study found that changes in $\mathrm{O}_{2}$ concentrations and flux of organic matter could change $\mathrm{N}_{2} \mathrm{O}$ consumption rates by up to one order of magnitude (Castro-González and Farías, 2004). As discussed, geochemical estimates may also suffer from uncertainties in water mass residence time and $\mathrm{N}_{2} \mathrm{O}$ loss or perturbations induced by local eddies. However, it seems unlikely that these uncertainties alone would account for the $3+$ orders of magnitude difference between laboratory and geochemical estimates in the literature. Part of the difference between laboratory measured and geochemically estimated $\mathrm{N}_{2} \mathrm{O}$ consumption rates may also be caused by $\mathrm{N}_{2} \mathrm{O}$ production occurring in the same waters in which $\mathrm{N}_{2} \mathrm{O}$ consumption occurs, which would lower the net apparent consumption rates with respect to what would be observed in the laboratory. Another uncertainty is that $\mathrm{N}_{2} \mathrm{O}$ production in regions of net $\mathrm{N}_{2} \mathrm{O}$ consumption via nitrifierdenitrification or heterotrophic denitrification could reduce the net consumption rate while not affecting the instantaneous consumption rate.

Due to uncertainty in consumption rates, previous $\mathrm{N}_{2} \mathrm{O}$ models have either not dealt with $\mathrm{N}_{2} \mathrm{O}$ consumption at all (Nevison et al., 2003; Schmittner and Galbraith, 2008; Bianchi et al., 2012), have arbitrarily assumed a linear drop in $\mathrm{N}_{2} \mathrm{O}$ production down to zero after the switching point (Suntharalingam et al., 2000), or have modelled it on a firstorder reaction based on substrate (i.e., $\mathrm{NO}_{3}^{-}$) concentrations (Jin and Gruber, 2003). Here, we used the UVic model to test the sensitivity of $\mathrm{N}_{2} \mathrm{O}$ concentrations within the ETP to different values of $\mathrm{N}_{2} \mathrm{O}$ consumption. Although there is a great deal of uncertainty in consumption values, we find that average modelled $\mathrm{N}_{2} \mathrm{O}$ concentrations are relatively insensitive to uncertainties in consumption rates, affecting estimates by $<10 \%$ (Fig. 6b). Thus, the $\mathrm{N}_{2} \mathrm{O}$ consumption rate estimate of $0.01-1 \mathrm{mmol} \mathrm{N}_{2} \mathrm{O} \mathrm{m}^{-3} \mathrm{yr}^{-1}$ provides an approximate value for consumption rates in the PCUC area, although
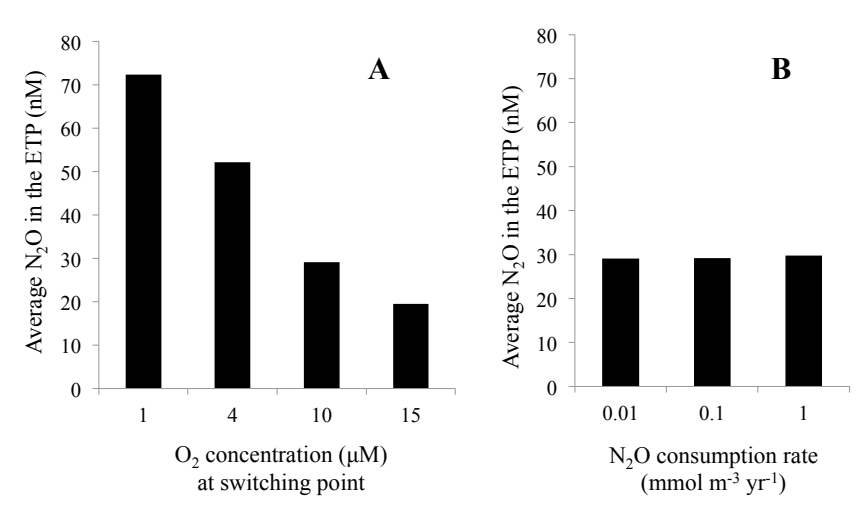

Fig. 6. Sensitivity of average modelled $\mathrm{N}_{2} \mathrm{O}$ concentrations in the Eastern Tropical Pacific (ETP) between $80-150^{\circ} \mathrm{W}$, $23.5^{\circ} \mathrm{N}-23.5^{\circ} \mathrm{S}$, and $150-2000 \mathrm{~m}$ to (a) the $\mathrm{O}_{2}$ concentration at which $\mathrm{N}_{2} \mathrm{O}$ consumption begins (assuming an $\mathrm{N}_{2} \mathrm{O}$ consumption rate of $0.129 \mathrm{mmol} \mathrm{m}^{-3} \mathrm{yr}^{-1}$ ), and (b) $\mathrm{N}_{2} \mathrm{O}$ consumption rate $\left(\mathrm{mmol} \mathrm{m}^{-3} \mathrm{yr}^{-1}\right.$ ) (assuming a switching point of $10 \mathrm{mmol}$ $\left.\mathrm{O}_{2} \mathrm{~m}^{-3}\right)$.

obviously further work is necessary to better characterise marine $\mathrm{N}_{2} \mathrm{O}$ consumption for the greater ETP region.

\subsection{The switch between net $\mathrm{N}_{2} \mathrm{O}$ production and consumption}

It is well known that as oxygen concentrations are reduced, eventually net $\mathrm{N}_{2} \mathrm{O}$ production switches to net $\mathrm{N}_{2} \mathrm{O}$ consumption, presumably due to denitrification. However, the exact $\mathrm{O}_{2}$ concentration at which net $\mathrm{N}_{2} \mathrm{O}$ consumption begins is not well defined and may not be consistent among regions. Models estimating $\mathrm{N}_{2} \mathrm{O}$ production have previously used values of $1-4.5 \mu \mathrm{M} \mathrm{O}_{2}$ (Suntharalingam et al., 2000; Nevison et al., 2003; Jin and Gruber, 2003; Freing et al., 2009; Bianchi et al., 2012). However, literature estimates specific to the ETP place the switching point between 5$20 \mathrm{\mu M} \mathrm{O}_{2}$ (Nevison et al., 2003; Farías et al., 2009; Cornejo and Farías, 2012; Ryabenko et al., 2012), indicating that the switching point may be higher than models have so far accounted for in this region. In this section, we identify the $\mathrm{O}_{2}$ concentration that best represents the point at which net $\mathrm{N}_{2} \mathrm{O}$ production switches to net $\mathrm{N}_{2} \mathrm{O}$ consumption for application in biogeochemical models of the ETP.

The uncertainty in the point at which net $\mathrm{N}_{2} \mathrm{O}$ consumption begins has important implications for modelling $\mathrm{N}_{2} \mathrm{O}$ production in the ETP. Based on a sensitivity analysis, different literature values for the $\mathrm{O}_{2}$ switching point yield up to a $22 \%$ difference in expected ETP $\mathrm{N}_{2} \mathrm{O}$ concentrations (Fig. 6). The large variability in expected $\mathrm{N}_{2} \mathrm{O}$ concentrations is due to water volume. Based on mean corrected World Ocean Atlas 2005 data (Bianchi et al., 2012), the volume of water in the ETP that contains $\leq 5 \mu \mathrm{MO}_{2}$ is $\sim 6 \times$ smaller than that which contains $\leq 20 \mu \mathrm{MO}_{2}$. Thus, a switching point at 5 vs. $20 \mu \mathrm{M}$ results in a disproportionately small volume of 
Table 1. Estimated $\mathrm{N}_{2} \mathrm{O}$ consumption rates within the Peru-Chile Under Current (PCUC) based on a range of estimated water mass residence times and on observed decreases $\mathrm{N}_{2} \mathrm{O}$ concentrations for two separate cruises. Further details on the models and calculations presented below can be found in Appendix C.

\begin{tabular}{|c|c|c|c|c|c|}
\hline Data source ${ }^{a}$ & $\begin{array}{r}\text { Ventilation } \\
\text { rate }(\mathrm{Sv})\end{array}$ & Volume $\left(\mathrm{m}^{3}\right)$ & $\begin{array}{r}\text { Residence } \\
\text { time (yr) }\end{array}$ & $\begin{array}{c}\mathrm{N}_{2} \mathrm{O} \text { loss } \\
\left(\mathrm{mmol} \mathrm{m}^{-3}\right)\end{array}$ & $\begin{array}{r}\text { Estimated } \mathrm{N}_{2} \mathrm{O} \\
\text { consumption rate } \\
\left(\mathrm{mmol} \mathrm{m}^{-3} \mathrm{yr}^{-1}\right)\end{array}$ \\
\hline \multicolumn{6}{|l|}{ PCUC, between 26.3-26.5 $\sigma_{\theta}$} \\
\hline \multicolumn{6}{|c|}{ NITROP-85 cruise $1\left(7.7-16^{\circ} \mathrm{S}, 1985\right)[1]$} \\
\hline Model-derived annual average (MOM4) [2] & 0.11 & $1.1 \times 10^{12}$ & 0.31 & 0.0264 & 0.084 \\
\hline Model-derived annual average (ROMS) [3] & 0.167 & $5.4 \times 10^{12}$ & 1.02 & 0.0264 & 0.026 \\
\hline \multicolumn{6}{|c|}{$\mathrm{M} 77 / 3$ and $\mathrm{M} 77 / 4\left(6-14^{\circ} \mathrm{S}, 2009\right)[4]$} \\
\hline Model-derived annual average (MOM4) [2] & 0.06 & $5.8 \times 10^{11}$ & 0.32 & 0.0407 & 0.129 \\
\hline Model-derived annual average (ROMS) [3] & 0.13 & $4.1 \times 10^{12}$ & 1.01 & 0.0407 & 0.040 \\
\hline Observed instantaneous value, Feb 2009 [5] & 1.01 & $5.8 \times 10^{11^{\mathrm{b}}}$ & $0.02^{\mathrm{b}}$ & 0.0407 & 2.035 \\
\hline Observed instantaneous value, Feb 2009 [5] & 1.01 & $4.1 \times 10^{12^{\mathrm{c}}}$ & $0.13^{\mathrm{c}}$ & 0.0407 & 0.313 \\
\hline \multicolumn{6}{|l|}{ Entire PCUC } \\
\hline Model-derived annual average (MOM4) [2] & 4.0 & - & - & - & - \\
\hline Model-derived annual average (ROMS) [3] & 1.8 & - & - & - & - \\
\hline Model-derived annual average (ROccam) [6] & 3.9 & - & - & - & - \\
\hline Model-derived annual average (RSoda) [6] & 4.9 & - & - & - & - \\
\hline Model-derived annual average (Uvic-ESCM) [7] & 0.2 & - & - & - & - \\
\hline Observed instantaneous value [8] & $2-4$ & - & - & - & - \\
\hline
\end{tabular}

a References are as follows: (1) Friederich et al. (1992); (2) Zamora et al. (2011); (3) Montes et al. (2011) and I. Montes, personal communication; (4) Kock and Löscher, unpublished data; (5) Czeschel et al. (2011), Fig. 3f; (6) Montes et al. (2010); (7) this study, not used for calculation due to coarse resolution; (8) Wyrtki (1963).

$\mathrm{b}$ Based on the MOM4-derived annual average volume.

${ }^{\mathrm{c}}$ Based on the ROMS-derived annual average volume.

water in which $\mathrm{N}_{2} \mathrm{O}$ can be consumed. Therefore, it is critical to correctly identify the $\mathrm{O}_{2}$ concentration at which net $\mathrm{N}_{2} \mathrm{O}$ production changes to net $\mathrm{N}_{2} \mathrm{O}$ consumption in order to correctly predict $\mathrm{N}_{2} \mathrm{O}$ concentrations in the ocean. This finding is in line with a recent study by Bianchi et al. (2012), which found that even without accounting for active $\mathrm{N}_{2} \mathrm{O}$ consumption, global marine $\mathrm{N}_{2} \mathrm{O}$ production was sensitive to the oxygen concentration at which net $\mathrm{N}_{2} \mathrm{O}$ production stops.

Cornejo and Farías (2012) recently proposed using the development of subsurface nitrite $\left(\mathrm{NO}_{2}^{-}\right)$as a proxy for $\mathrm{N}_{2} \mathrm{O}$ consumption for the coastal eastern tropical South Pacific. $\mathrm{NO}_{2}^{-}$is frequently associated with $\mathrm{N}_{2} \mathrm{O}$ depletion; also, both $\mathrm{NO}_{2}^{-}$reduction and $\mathrm{N}_{2} \mathrm{O}$ production are inhibited at very low $\mathrm{O}_{2}$ levels (Farías et al., 2007). As indicated in Fig. 7, subsurface $\mathrm{NO}_{2}^{-}$accumulation in the ETP is also associated with low $\mathrm{N}^{*}$ and $\mathrm{O}_{2}$, both indicators of denitrification. Based on $\mathrm{NO}_{2}^{-}$concentrations $>0.75 \mu \mathrm{M}$, Cornejo and Farías (2012) identified the beginning of net $\mathrm{N}_{2} \mathrm{O}$ consumption at $8 \mu \mathrm{M} \mathrm{O}_{2}$ in the coastal eastern tropical South Pacific; $\mathrm{NO}_{2}^{-}$accumulation has also been related to $\mathrm{N}_{2} \mathrm{O}$ consumption in the eastern tropical North Pacific (Cohen and Gordon, 1978).

One problem with applying this approach to a scale is that $\mathrm{NO}_{2}^{-}$may not be a good indicator of denitrification in all circumstances, even when the $\mathrm{NO}_{2}^{-}$is accompanied by low $\mathrm{N}^{*}$ and low $\mathrm{O}_{2}$ (Nicholls et al., 2007; Naqvi et al., 2010;
Lam et al., 2011). Although $\mathrm{NO}_{2}^{-}, \mathrm{N}_{2} \mathrm{O}$, low $\mathrm{O}_{2}$, and low $\mathrm{N}^{*}$ can all be associated with water column denitrification, other processes such as anammox, sedimentary denitrification, dissimilatory nitrate reduction to ammonia, stand-alone $\mathrm{NO}_{3}^{-}$reduction to $\mathrm{NO}_{2}^{-}$and nitrification can affect the concentrations of these species as well. Additionally, accumulation of each can occur on different timescales, and each can also be passively transported.

Therefore, we use the MEMENTO database to test if $\mathrm{NO}_{2}^{-}$ is a good proxy for $\mathrm{N}_{2} \mathrm{O}$ consumption over a larger region of the ETP than that described in Cornejo and Farías (2012) (the region in the MEMENTO database that includes $\mathrm{NO}_{2}^{-}$ data spans between $20^{\circ} \mathrm{N}-21^{\circ} \mathrm{S}$ and $70-110^{\circ} \mathrm{W}$, Fig. 7). We find that when $\mathrm{NO}_{2}^{-}$is low, $\mathrm{N}_{2} \mathrm{O}$ production rates cover a range of values; conversely, when $\mathrm{NO}_{2}^{-}$is above detection limits $(\sim 0.1 \mu \mathrm{M}), \mathrm{N}_{2} \mathrm{O}$ production rates are almost always $<0.25 \mathrm{nmol} \mathrm{kg}^{-1} \mathrm{yr}^{-1}$ (Fig. 7a). Thus, $\mathrm{NO}_{2}^{-}$appears to be a reliable proxy for $\mathrm{N}_{2} \mathrm{O}$ consumption in the greater ETP although the mechanisms for why these processes are associated are not entirely clear. It is possible that this cooccurrence is related to nitrifier-denitrification, which can occur in aerobic environments in response to the presence of $\mathrm{NO}_{2}^{-}$(Beaumont et al., 2004). Another possibility for their relatedness in situ is that both $\mathrm{NO}_{2}^{-}$and $\mathrm{N}_{2} \mathrm{O}$ reductase appear to be inhibited at lower $\mathrm{O}_{2}$ levels than other relevant 


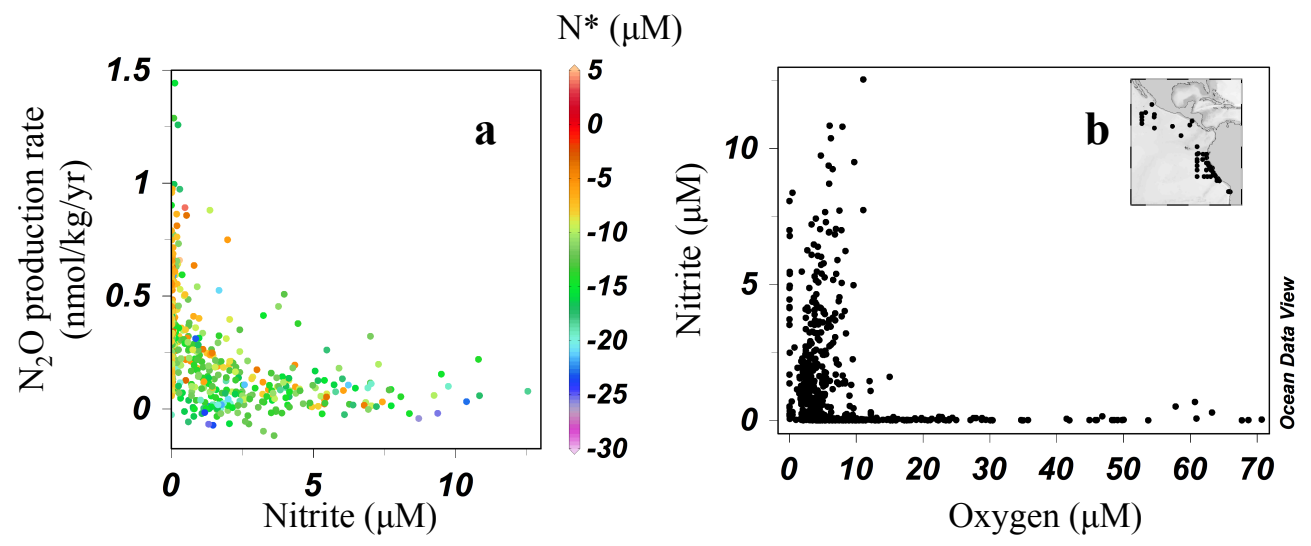

Fig. 7. (a) ETP $\mathrm{N}_{2} \mathrm{O}$ production rate $\left(\mathrm{N}_{2} \mathrm{OPR}\right)$ vs. $\mathrm{NO}_{2}^{-}$and $\mathrm{N}^{*}$ in the Eastern Tropical Pacific $(\mathrm{ETP}),(\mathbf{b}) \mathrm{NO}_{2}^{-}(\mu \mathrm{M})$ and $\mathrm{O}_{2}(\mu \mathrm{M})$ values in the ETP from depths $>150 \mathrm{~m}$. $\mathrm{NO}_{2}^{-}$accumulates at $\mathrm{O}_{2}<10 \mu \mathrm{M}$.

enzymes involved in the $\mathrm{N}$ cycle (Körner and Zumft, 1989; Coyne and Tiedje, 1990; Mckenney et al., 1994; Farías et al., 2007).

Similarly to Cornejo and Farías (2012), we find that $\mathrm{NO}_{2}^{-}$ accumulation begins when $\mathrm{O}_{2}$ concentrations reach $\sim 8$ $10 \mu \mathrm{M}$ (Fig. 7b). If an $\mathrm{O}_{2}$ concentration of $\sim 10 \mu \mathrm{M} \mathrm{O}_{2}$ is a more realistic switching point than the $1-4 \mu \mathrm{M}$ parameterised in previous models, these models may have vastly overestimated $\mathrm{N}_{2} \mathrm{O}$ production in the ETP due to underestimating the volume involved in $\mathrm{N}_{2} \mathrm{O}$ consumption.

Interestingly, others have reported lower points at which $\mathrm{NO}_{2}^{-}$accumulates (e.g., $4 \mu \mathrm{M} \mathrm{O}_{2}$ in the eastern tropical North Pacific (Cline and Richards, 1972) and $2.5 \mu \mathrm{M} \mathrm{O}_{2}$ in the Arabian Sea (Morrison et al., 1998; Codispoti et al., 2001)). The difference in the $\mathrm{O}_{2}$ concentration at which $\mathrm{NO}_{2}^{-}$accumulates and presumably $\mathrm{N}_{2} \mathrm{O}$ consumption occurs indicates that there may be some fundamental difference between and within systems, perhaps due to the availability of organic matter or presence of specific nitrate reducing organisms in these regions.

\subsection{Depth and temperature dependency of $\mathrm{N}_{2} \mathrm{O}$ production}

Previously, $\mathrm{N}_{2} \mathrm{O}$ production rates from marine nitrification have been suggested to have a temperature dependence (Elkins et al., 1978; Butler et al., 1989). However, this hypothesis has not been strongly supported by laboratory and field studies (Nevison et al., 2003; Punshon and Moore, 2004; Ward, 2008). Based on thermodynamic considerations, pressure has also been suggested to affect $\mathrm{N}_{2} \mathrm{O}$ production rates (Butler et al., 1989), but again, we are not aware of any laboratory studies supporting this hypothesis.

To test for in situ evidence for a depth/temperature dependency, multiple previous studies have used plots of the biotic $\mathrm{N}_{2} \mathrm{O} / \mathrm{AOU}$ ratio vs. depth (Elkins et al., 1978; Butler et al., 1989; Suntharalingam and Sarmiento 2000; Fre- ing et al., 2009; Cornejo and Farías, 2012). These studies have produced patterns that they considered to be evidence for a depth/temperature effect. However, the temperaturesensitivity of nitrification rates is nonlinear and may be masked or superseded by the dynamics of $\mathrm{O}_{2}$ consumption (Barnard et al., 2005). Additionally, the biotic $\mathrm{N}_{2} \mathrm{O} / \mathrm{AOU}$ ratio reflects the integrated history of depths of the water mass, rather than its current depth, making this ratio an imperfect measure for testing a depth or temperature dependence hypothesis. The MEMENTO data showed a similar pattern to these previous studies at first appearance. However, the depth-dependency pattern was confounded with $\mathrm{O}_{2}$ levels and the pattern disappeared after correcting for $\mathrm{O}_{2}$ (Fig. 8). While the focus of this manuscript is not on temperature or depth dependencies, we briefly note that these results call into question what was previously thought to be in situ evidence for the pressure/ $T$ dependency hypotheses.

\section{Conclusions}

Our findings support a growing body of work that indicates that $\mathrm{N}_{2} \mathrm{O}$ consumption is occurring on a larger regional scale in the Pacific than initially expected. Previous models assume that net $\mathrm{N}_{2} \mathrm{O}$ consumption begins at an $\mathrm{O}_{2}$ concentration of $4 \mu \mathrm{M}$ or lower. Our data indicate, based on TTD methods shown to robustly separate biotic and abiotic $\mathrm{N}_{2} \mathrm{O}$ sources in the ETP, that $\mathrm{N}_{2} \mathrm{O}$ consumption begins at $\sim 10 \mu \mathrm{M} \mathrm{O}$. Because ETP waters containing $\geq 10 \mu \mathrm{MO}_{2}$ have $3.5 \times$ the volume of waters that contain $\geq 4 \mu \mathrm{M} \mathrm{O}_{2}$, using a 4 vs. $10 \mu \mathrm{MO}_{2}$ switching point results in a $14 \%$ overestimate in $\mathrm{N}_{2} \mathrm{O}$ concentrations within the ETP. Thus, it is particularly important that models of $\mathrm{N}_{2} \mathrm{O}$ production in expanding OMZs correctly identify the $\mathrm{O}_{2}$ concentration at which net $\mathrm{N}_{2} \mathrm{O}$ production switches to net consumption. 

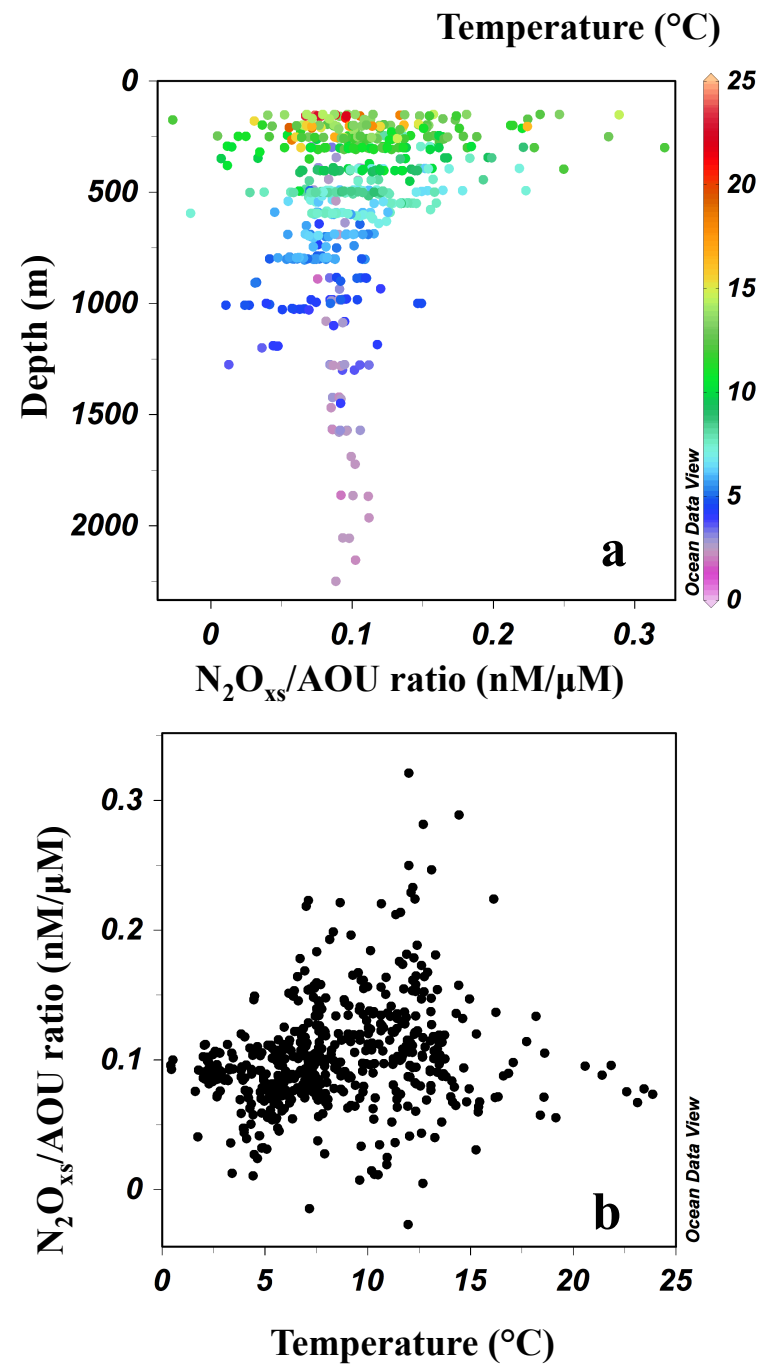

Fig. 8. $\mathrm{O}_{2}$-corrected $\mathrm{N}_{2} \mathrm{O}_{\mathrm{xs}} / \mathrm{AOU}$ ratios $(\mathrm{nM} / \mu \mathrm{M})$ vs. depth $(\mathrm{m})$ and temperature $\left({ }^{\circ} \mathrm{C}\right)$ for MEMENTO profiles shown in Fig. 2. $\mathrm{O}_{2}$ dependency was corrected for by the linear relationship shown in Fig. 5, standardised to a fixed level of $276 \mu \mathrm{M} \mathrm{O}_{2}$, the highest $\mathrm{O}_{2}$ concentration observed in the selected data. Samples likely to be influenced by denitrification were excluded (see Sect. 2.3 for exclusion criteria). Note: in order to show detail, two outliers with high $\mathrm{N}_{2} \mathrm{O}_{\mathrm{xs}}$ /AOU ratios were excluded in the figures above.

Our results also suggest that subsurface $\mathrm{N}_{2} \mathrm{O}$ production at low $\mathrm{O}_{2}$ concentrations remains nearly steady at about $0.00048 \mathrm{nmol} \mathrm{N}_{2} \mathrm{O}$ produced per $\mu \mathrm{mol} \mathrm{O}_{2}$ consumed rather than increasing exponentially as previously expected. This finding, combined with a larger volume of water in which $\mathrm{N}_{2} \mathrm{O}$ consumption occurs, points towards lower net regional $\mathrm{N}_{2} \mathrm{O}$ production than estimated previously.

The dynamics of $\mathrm{N}_{2} \mathrm{O}$ production at low $\mathrm{O}_{2}$ concentrations are particularly important to constrain because oxygen minimum zones are thought likely to expand in the near future. To date, the response of $\mathrm{N}_{2} \mathrm{O}$ production to expanding dexoxygenation is still highly uncertain due, in large part, to poorly constrained $\mathrm{N}_{2} \mathrm{O}$ consumption rates - the consumption rates were uncertain enough that many previous studies have not accounted for $\mathrm{N}_{2} \mathrm{O}$ consumption at all. We find that $\mathrm{N}_{2} \mathrm{O}$ consumption rates in the Peru-Chile Undercurrent are on the order of $0.01-1 \mathrm{mmol} \mathrm{N}_{2} \mathrm{O} \mathrm{m}^{-3} \mathrm{yr}^{-1}$. This value is several orders of magnitude lower than laboratory estimates of $\mathrm{N}_{2} \mathrm{O}$ consumption rates, but is consistent with other geochemical estimates for the ETP. However, it is uncertain how representative this value is of the overall ETP because $\mathrm{N}_{2} \mathrm{O}$ consumption rates may vary due to local organic matter abundance and oxygen concentrations (Castro-González and Farías, 2004).

In order to improve estimates of $\mathrm{N}_{2} \mathrm{O}$ production in the ETP, much more data on consumption rates is needed. If there is an increase in the volume of water in which net $\mathrm{N}_{2} \mathrm{O}$ consumption occurs, it is possible that an expansion of the OMZs will cause average $\mathrm{N}_{2} \mathrm{O}$ concentrations in the Pacific to decrease rather than increase.

\section{Appendix A}

\section{Description of the transit time distribution (TTD) method}

To determine the $\Delta / \Gamma$ ratio used in Eq. (1), we compared measured Pacific pCFC-12 age and tritium values with the TTD-derived values of pCFC-12 age and tritium associated with various $\Delta / \Gamma$ ratios (Fig. A1).

The TTD-derived tracer concentrations were calculated as follows:

$\mathrm{CFC}-12_{(r, t)}^{\mathrm{TTD}}=\int_{0}^{\infty} c_{\mathrm{o}}\left(t-t^{\prime}\right) G\left(r, t^{\prime}\right) \mathrm{d} t^{\prime}$

${ }^{3} H_{(r, t)}^{\mathrm{TTD}}=\int_{0}^{\infty} c_{\mathrm{o}}\left(t-t^{\prime}\right) e^{-\lambda t^{\prime}} G\left(r, t^{\prime}\right) \mathrm{d} t^{\prime}$

where the TTD-derived tracer concentrations at a given point in space, $r$, and a given time, $t$, are a function of $c_{\mathrm{O}}$ (the input function of CFC-12 or ${ }^{3} \mathrm{H}$ at the sea surface) and, for ${ }^{3} \mathrm{H}$, $e^{-\lambda t^{\prime}}$ (the radioactive decay term of ${ }^{3} \mathrm{H}$ into ${ }^{3} \mathrm{He}$ ), where $\lambda$ is the decay rate of tritium into tritogenic $\mathrm{He}\left(0.05576 \mathrm{yr}^{-1}\right.$; Unterweger et al., 1980). The data shown in Fig. A1 are WOCE tritium data collected from 1989-1993 that were then normalised to tritium values expected in 1991.

The surface water pCFC-12 source function for the North Pacific was obtained using northern hemisphere atmospheric CFC-12 values from Walker et al. (2000), adapted up to 2008 using data from Bullister (2011) and using CFC-12 solubility coefficients from Warner and Weiss (1985). The surface water tritium source function for the North Pacific was obtained from Stark et al. (2004) using three latitudinal bands of surface tritium input for the tropics $\left(0-20^{\circ} \mathrm{N}\right)$, subtropics $(20$ $\left.40^{\circ} \mathrm{N}\right)$ and subpolar regions $\left(40-60^{\circ} \mathrm{N}\right)$. Due to a paucity 

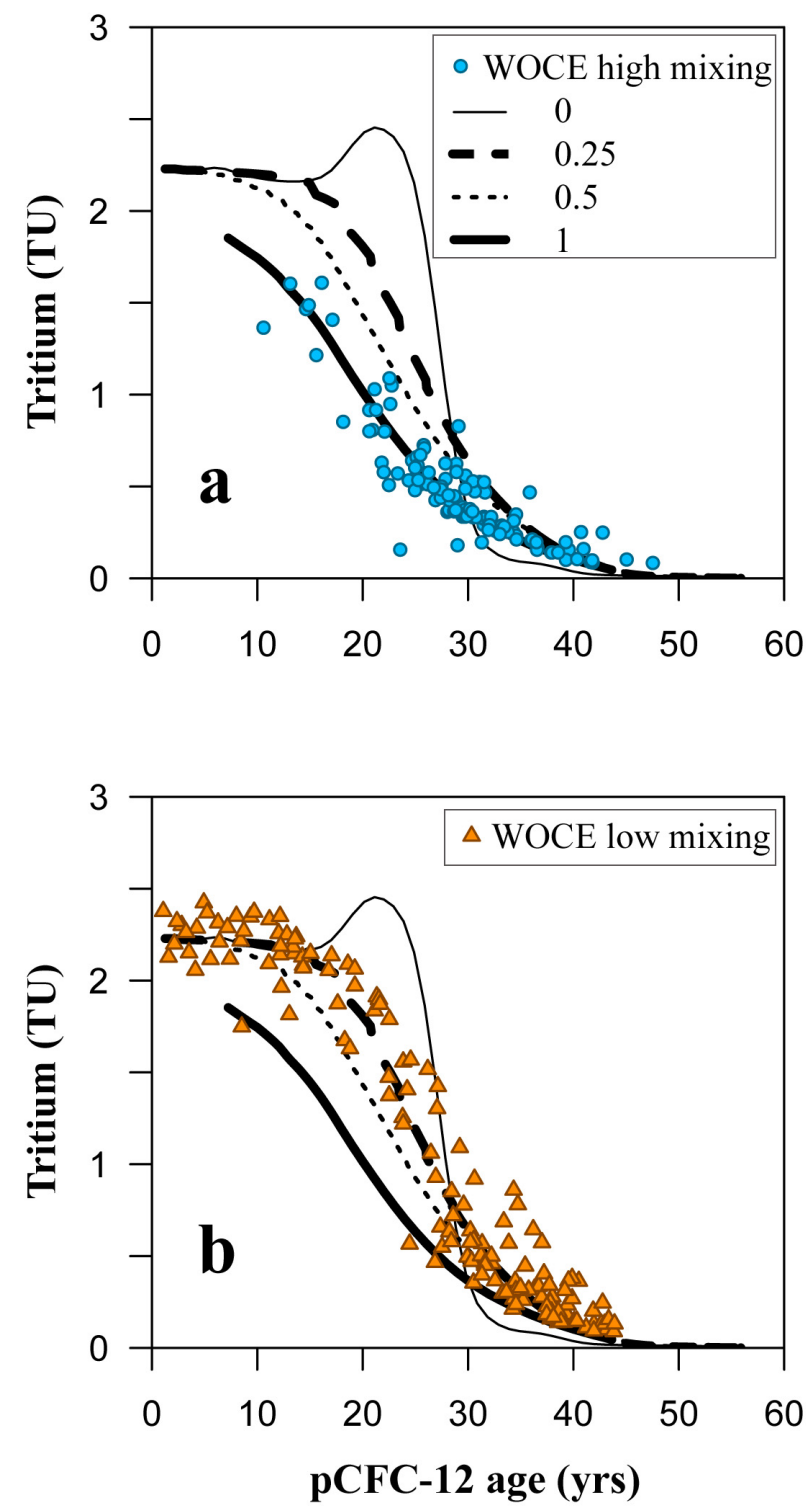

Fig. A1. The relationship between North Pacific pCFC-12 age and tritium concentrations normalised to year 1991 for observations and TTD-estimates based on Eqs. (A1) and (A2). Observations (blue circles and yellow triangles) are from WOCE cruises PO4E (1989), P16C (1991), P17C (1991), P17N (1993), and P19C (1993). Observations are classified as "high mixing" (surface nitrate concentrations $>1 \mu \mathrm{M}$ ) and "low mixing" samples (surface nitrate concentrations $<1 \mu \mathrm{M}$ ) (see text for discussion on selection criteria). Samples with tracer concentrations below detection limits (i.e., CFC-12 concentrations $<0.01 \mathrm{pM} ;{ }^{3} \mathrm{H}<0.08 \mathrm{TU}$ ) have been excluded. Black lines indicate the TTD-estimated pCFC-12 age and tritium values assuming a $\Gamma / \Delta$ ratio of $0,0.25,0.5$, and 1 (thin solid, dashed, dotted and thick solid lines, respectively). "High mixing" samples fit the ratio 1 line very well $\left(R^{2}=0.95\right.$, total sum of square error technique) and "low mixing" samples fit the 0.25 ratio line well $\left(R^{2}=0.85\right)$.

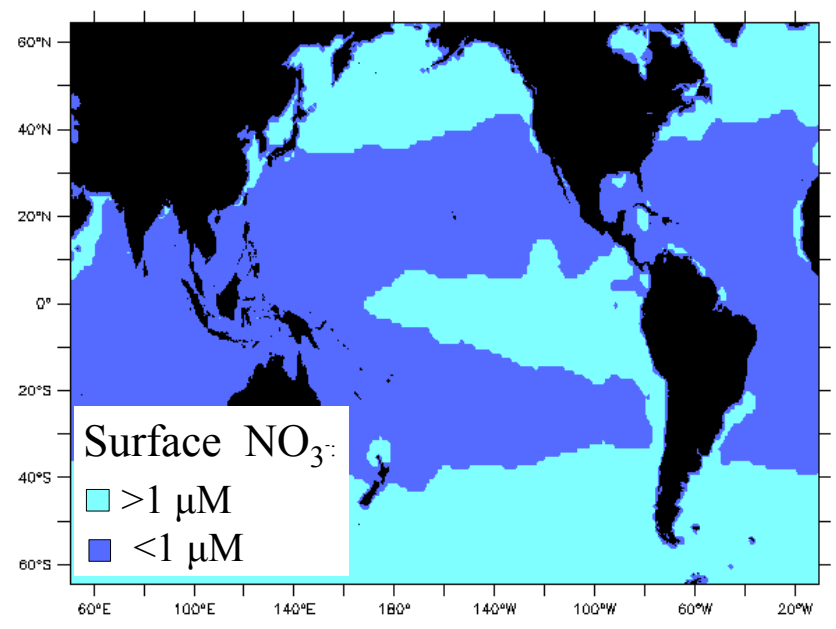

Fig. A2. Regions of the Pacific and surrounding regions where surface nitrate $\left(\mathrm{NO}_{3}^{-}\right)$concentrations are above and below $1 \mu \mathrm{M}$. Based on annual 1-degree World Ocean Atlas 2009 data (Garcia et al., 2010a).

of data, accurate tritium inputs for the South Pacific were unavailable. Therefore, we focus our attention on data from the North Pacific, with ramifications discussed below. Both CFC-12 and tritium data are available from the World Ocean Circulation Experiment (WOCE) dataset (www.ewoce.org). As detailed in Sect. 2.2, the pCFC-12 age was calculated from $\mathrm{CFC}-12$ concentrations based on atmospheric histories of CFC-12 and CFC-12 solubility.

Waters where upwelling is a dominant process are highly mixed. Thus, we approximated the degree of upwellingderived mixing using surface nitrate concentrations from the annual 1-degree World Ocean Atlas 2009 (Garcia et al., 2009). Samples with "low" and "high" upwelling-derived mixing were classified by having surface nitrate concentrations of $<1 \mu \mathrm{M}$ and $>1 \mu \mathrm{M}$, respectively (Fig. A2). Samples collected throughout the North Pacific indicate that a $\Delta / \Gamma$ ratio of 1 provides an accurate fit to observations in regions with high upwelling (such as the equatorial Pacific). In regions with low upwelling-derived mixing, a $\Delta / \Gamma$ ratio of 0.25 provides a better fit to the data (see Fig. A1).

Note that the data presented in Fig. A1 exclude southern hemisphere samples due to the lack of tritium data. For the MEMENTO data in the Southern Hemisphere, we assume that the relationship between upwelling-derived mixing and $\Delta / \Gamma$ ratios is similar in the North and South Pacific. This assumption is supported by previously published global model estimates of $\Delta$ and $\Gamma$ (Peacock and Maltrud, 2005) that indicate that the patterns in $\Delta / \Gamma$ ratios are similar in the North and South Pacific.

Using a matrix containing individual $\Delta$ and $\Gamma$ values and the corresponding TTD-derived pCFC-12 age, we determined each sample's $\Gamma$ value by searching for the unique $\Gamma$ value that corresponded to that sample's pCFC-12 age and 
$\Delta / \Gamma$ ratio. Because age tracer data were not available for the MEMENTO cruises, as in Freing et al. (2012) we used GLODAP gridded CFC-12 data (Key et al., 2004) for the calculation of $\Gamma$ at the MEMENTO sites. Based on GLODAP gridded CFC-12 errors (Key et al., 2004), the median uncertainty in $\mathrm{N}_{2} \mathrm{O}_{\mathrm{xs}}$ and $\mathrm{N}_{2} \mathrm{OPR}$ values resulting from extrapolating CFC-12 data to the collection sites was, respectively, $3 \%$ and $31 \%$.

\section{Appendix B}

\section{Additional description of the UVic-ESCM}

In the UVic-ESCM, the atmosphere is treated as one layer with homogeneous concentrations of atmospheric $\mathrm{CO}_{2}, \mathrm{O}_{2}$, CFC-12 and $\mathrm{N}_{2} \mathrm{O}$. The UVic-ESCM was initialised with World Ocean Atlas 2009 temperature (Locarnini et al., 2010), salinity (Antonov et al., 2010), oxygen (Garcia et al., 2010b), as well as nitrate and phosphate data (Garcia et al., 2010a). Each experiment was spun up for $13800 \mathrm{yr}$ under preindustrial atmospheric and astronomical boundary conditions before historical conditions were implemented for year 1744 and onwards, including increasing atmospheric $\mathrm{N}_{2} \mathrm{O}$ (Holland et al., 2005), $\mathrm{CO}_{2}$ and CFC-12 concentrations (Bullister, 2011) up to the year 2008. Atmospheric $\mathrm{CO}_{2}$ was anthropogenically forced after 1744 and atmospheric $\mathrm{O}_{2}$ was held constant. The UVic-ESCM resolves seasonal cycles, but does not incorporate large-scale climatological events like the El Niño Southern Oscillation.

\section{Appendix C}

\section{Description of the calculations and model versions in Table 1}

Here we provide more details on the calculations and different model versions used in Table 1 . The $\mathrm{N}_{2} \mathrm{O}$ data used to derive $\mathrm{N}_{2} \mathrm{O}$ loss were based on two datasets (see Fig. 4 for a map of the station locations). The NITROP-85 cruise, described in detail in Friederich et al. (1992), took place in February, 1985 and proceeded southward along the PCUC from 7.7 $-16^{\circ} \mathrm{S}$. The second dataset (the Meteor 77, or M77, cruise) was sampled in February, 2009 from the region surrounding $6-14^{\circ} \mathrm{S}$. Only two stations from the M77 cruise were within the PCUC as based on the co-sampled current data presented in Czeschel et al. (2011), and so only these stations were compared to the NITROP- 85 dataset. $\mathrm{N}_{2} \mathrm{O}$ loss was determined from the change in $\mathrm{N}_{2} \mathrm{O}$ concentrations between transit based on a linear model fit to the data (shown in Fig. 4). $\mathrm{N}_{2} \mathrm{O}$ loss was based on measurements gathered within the 26.3 and $26.5 \sigma_{\theta}$ density layer.

The ventilation rate $(\mathrm{Sv})$ and volume $\left(\mathrm{m}^{3}\right)$ of the water were calculated from several models of the region as well as observations gathered during the 2009 M77 cruise (de- scribed in Czeschel et al., 2011) and a September-December 1960 cruise from $5-24^{\circ} \mathrm{S}$ described in Wyrtki (1963). The Modular Ocean Model 4 had a $1^{\circ} \times 1^{\circ}$ horizontal resolution and 50 vertical layers, and was run using CORE climatological forcing from Large and Yeager (2004). We initialised the model with World Ocean Atlas 2001 annual mean salinity and temperature (Boyer et al., 2002). The UVic-ESCM (also described in Sect. 2.3) had a $3.6^{\circ} \times 1.8^{\circ}$ horizontal resolution and 19 vertical layers, and was initialised based on World Ocean Atlas 2009 salinity and temperature (Antonov et al., 2010; Locarnini et al., 2010). The ROMS model, described in Montes et al. (2011) had a 1/9 $\times 1 / 9^{\circ}$ horizontal resolution and 32 terrain-following vertical layers, and was initialised based on QuikSCAT satellite scatterometer wind stress data (Liu et al., 1998) and COADS ocean surface monthly climatology (da Silva et al., 1994). For the ROMS model, we used data from the mean annual conditions, rather than from the El Niño and La Niña scenarios also presented in Montes et al. (2011). The output of these models in the entire PCUC was compared with literature ROccam and RSoda model calculations of the ventilation rate for the entire PCUC presented in Montes et al. (2010).

When calculating ventilation rate and volume from model output, we used a similar definition of the PCUC as Montes et al. (2011). Criteria were a net southward flow of $>1 \mathrm{~cm} \mathrm{~s}^{-1}$ for locations less than $250 \mathrm{~km}$ from the coast and data had to be within the 26.3-26.5 $\sigma_{\theta}$ density range. Ventilation rate $(\mathrm{Sv})$ was calculated from the product of the average southward flow $\left(\mathrm{m} \mathrm{yr}^{-1}\right)$ for the PCUC and the area $\left(\mathrm{m}^{2}\right)$ in which PCUC water flowed out of the region of interest (as defined by either $7.7-16^{\circ} \mathrm{S}$ or $6-14^{\circ} \mathrm{S}$ ). Volume was calculated from the total volume of model grids available that satisfied the PCUC criteria. Residence time (yr) was calculated by volume $\left(\mathrm{m}^{3}\right)$ divided by ventilation rate $\left(\mathrm{m}^{3} \mathrm{yr}^{-1}\right) . \mathrm{N}_{2} \mathrm{O}$ consumption rate was then calculated by Eq. (5).

Acknowledgements. We thank R. Czeschel, A. Freing, J. Getzlaff, I. Montes, L. Stramma, T. Tanhua, and F. Wittke for help with this work and the people involved in the collection of the MEMENTO data. We would also like to thank N. Gruber, P. Suntharalingam, C. Deutsch, and an anonymous referee for helpful suggestions. Funding was provided by SOPRAN (FKZ 03F0611A) and SFB754.

The service charges for this open access publication have been covered by a Research Center of the Helmholtz Association.

Edited by: C. Heinze

\section{References}

Alldredge, A. L. and Cohen, Y.: Can microscale chemical patches persist in the sea? Microelectrode study of marine snow, fecal pellets, Science, 235, 689-691, doi:10.1126/science.235.4789.689, 1987. 
Altabet, M. A., Ryabenko, E., Stramma, L., Wallace, D. W. R., Frank, M., Grasse, P., and Lavik, G.: An eddy-stimulated hotspot for fixed nitrogen-loss from the Peru oxygen minimum zone, Biogeosciences Discuss., 9, 8013-8038, doi:10.5194/bgd9-8013-2012, 2012.

Antonov, J. I., Sedov, D., Boyer, T. P., Locarnini, R. A., Mishonov, A. V., and Garcia, H. E.: World Ocean Atlas 2009, Volume 2: Salinity, NOAA Atlas NESDIS 69, US Government Printing Office, 2010.

Bange, H. W.: Gaseous nitrogen compounds (NO, $\mathrm{N}_{2} \mathrm{O}, \mathrm{N}_{2}, \mathrm{NH}_{3}$ ) in the ocean, in: Nitrogen in the Marine Environment, edited by: Capone, D. G., Bronk, D. A., Mulholland, M. R., and Carpenter, E. J., 51-94, 2008.

Bange, H. W., Bell, T. G., Cornejo, M., Freing, A., Uher, G., UpstillGoddard, R. C., and Zhang, G.: MEMENTO: a proposal to develop a database of marine nitrous oxide and methane measurements, Environ. Chem., 6, 195-197, doi:10.1071/EN09033, 2009.

Bange, H. W., Freing, A., Kock, A., and Löscher, C. R.: Marine pathways to nitrous oxide, in Nitrous oxide and climate change, Earthscan, 36-62, 2010.

Barnard, R., Leadley, P. W., and Hungate, B. A.: Global change, nitrification, and denitrification: A review, Global Biogeochem. Cy., 19, GB1007, doi:200510.1029/2004GB002282, 2005.

Beaumont, H. J. E., Lens, S. I., Reijnders, W. N. M., Westerhoff, H. V., and van Spanning, R. J. M.: Expression of nitrite reductase in Nitrosomonas europaea involves NsrR, a novel nitritesensitive transcription repressor, Mol. Microbiol. 54, 148-158, doi:10.1111/j.1365-2958.2004.04248.x, 2004.

Beman, J. M., Popp, B. N., and Alford, S. E.: Quantification of ammonia oxidation rates and ammonia-oxidizing archaea and bacteria at high resolution in the Gulf of California and eastern tropical North Pacific Ocean, Limnol. Oceanogr., 57, 711-726, doi:10.4319/lo.2012.57.3.0711, 2012.

Bianchi, D., Dunne, J. P., Sarmiento, J. L., and Galbraith, E. D.: Data-based estimates of suboxia, denitrification, and $\mathrm{N}_{2} \mathrm{O}$ production in the ocean and their sensitivities to dissolved $\mathrm{O}_{2}$, Global Biogeochem. Cy., 26, GB2009, doi:201210.1029/2011GB004209, 2012.

Boyer, E. W., Goodale, C. L., Jaworsk, N. A., and Howarth, R. W.: Anthropogenic nitrogen sources and relationships to riverine nitrogen export in the northeastern USA, Biogeochemistry, 57, 137-169, 2002.

Bullister, J. L.: Atmospheric CFC-11, CFC-12, CFC-113, $\mathrm{CCl}_{4}$, and $\mathrm{SF}_{6}$ Histories (1910-2011), Ocean $\mathrm{CO}_{2}$ Carbon Dioxide Information Analysis Center, http://cdiac.ornl.gov/oceans/new_ atmCFC.html, last access: 23 May 2012.

Butler, J. H., Elkins, J. W., James, W., Thompson, T. M., Thayne, M., and Egan, K. B.: Tropospheric and dissolved $\mathrm{N}_{2} \mathrm{O}$ of the West Pacific and East Indian Oceans during the El Niño southern oscillation event of 1987, J. Geophys. Res., 94, 14865-14877, 1989.

Castro-González, M. and Farías, L.: $\mathrm{N}_{2} \mathrm{O}$ cycling at the core of the oxygen minimum zone off northern Chile, Mar. Ecol.-Prog. Ser., 280, 1-11, doi:10.3354/meps280001, 2004.

Carlucci, A. F. and McNally, P. M.: Nitrification by marine bacteria in low concentrations of substrate and oxygen, Limnol. Oceanogr., 14, 736-739, 1969.
Charpentier, J., Farias, L., Yoshida, N., Boontanon, N., and Raimbault, P.: Nitrous oxide distribution and its origin in the central and eastern South Pacific Subtropical Gyre, Biogeosciences, 4, 729-741, doi:10.5194/bg-4-729-2007, 2007.

Cline, J. D. and Richards, F. A.: Oxygen deficient conditions and nitrate reduction in the eastern tropical North Pacific Ocean, Limnol. Oceanogr., 17, 885-900, 1972.

Cline, J. D., Wisegarver, D. P., and Kelly-Hansen, K.: Nitrous oxide and vertical mixing in the equatorial Pacific during the 1982-1983 El Niño, Deep-Sea Res. Part I, 34, 857-873, doi:10.1016/0198-0149(87)90041-0, 1987.

Codispoti, L. A.: Interesting times for marine $\mathrm{N}_{2} \mathrm{O}$, Science, 327 , 1339-1340, doi:10.1126/science.1184945, 2010.

Codispoti, L. and Christensen, J.: Nitrification, denitrification and nitrous oxide cycling in the eastern tropical South Pacific Ocean, Mar. Chem., 16, 277-300, doi:10.1016/0304-4203(85)90051-9, 1985.

Codispoti, L., Brandes, J. A., Christensen, J. P., Devol, A., Naqvi, S. W. A., Paerl, H. W., and Yoshinari, T.: The oceanic fixed nitrogen and nitrous oxide budgets: Moving targets as we enter the anthropocene?, Sci. Mar., 65, Supplement 2, 85-105, 2001.

Cohen, Y. and Gordon, L. I.: Nitrous oxide in the oxygen minimum of the eastern tropical North Pacific: evidence for its consumption during denitrification and possible mechanisms for its production, Deep-Sea Res., 25, 509-524, doi:10.1016/01466291(78)90640-9, 1978.

Cohen, Y. and Gordon, L. I.: Nitrous oxide production in the ocean, J. Geophys. Res., 84, 347-353, doi:197910.1029/JC084iC01p00347, 1979.

Cornejo, M. and Farías, L.: Following the $\mathrm{N}_{2} \mathrm{O}$ consumption in the oxygen minimum zone of the eastern South Pacific, Biogeosciences, 9, 3205-3212, doi:10.5194/bg-9-3205-2012, 2012.

Coyne, M. S. and Tiedje, J. M.: Induction of denitrifying enzymes in oxygen-limited Achromobacter cycloclastes continuous culture, FEMS Microbiol. Lett., 73, 263-270, doi:10.1111/j.15746968.1990.tb03949.x, 1990.

Czeschel, R., Stramma, L., Schwarzkopf, F. U., Giese, B. S., Funk, A., and Karstensen, J.: Mid-depth circulation of the eastern tropical South Pacific and its link to the oxygen minimum zone, J. Geophys. Res., 116, C01015, doi:201110.1029/2010JC006565, 2011.

da Silva, A. M., Young-Molling, C. C., and Levitus, S.: Atlas of Surface Marine Data 1994, vol. 1, Algorithms and Procedures, NOAA Atlas NESDIS, NOAA, 1994.

Denman, K. L., Brasseur, G., Chidthaisong, A., Ciais, P., Cox, P. M., Dickenson, R. E., Hauglustaine, D., Heinze, C., Holland, E., Jacob, D., Lohmann, U., Ramachandran, S., da Silva Dias, P. L., Wofsy, S. C., and Zhang, X.: Couplings Between Changes in the Climate System and Biogeochemistry, in: Climate Change 2007: The Physical Science Basis. Contribution of Working Group I to the Forth Assessment Report of the Intergovernmental Panel on Climate Change, edited by: Solomon, S., Qin, D., Manning, M., Chen, Z., Marquis, M., Averyt, K. B., Tignor, M., and Miller, H. L., Cambridge University Press, 2007.

Deutsch, C., Brix, H., Ito, T., Frenzel, H., and Thompson, L.: Climate-forced variability of ocean hypoxia, Science, 333, 336339, doi:10.1126/science.1202422, 2011.

Dore, J. E. and Karl, D. M.: Nitrification in the euphotic zone as a source for nitrite, nitrate, and nitrous oxide 
at Station ALOHA, Limnol. Oceanogr., 41, 1619-1628, doi:10.4319/lo.1996.41.8.1619, 1996.

Dore, J. E., Popp, B. N., Karl, D. M., and Sansone, F. J.: A large source of atmospheric nitrous oxide from subtropical North Pacific surface waters, Nature, 396, 63-66, doi:10.1038/23921, 1998.

Elkins, J. W., Wofsy, S. C., McElroy, M. B., Kolb, C. E., and Kaplan, W. A.: Aquatic sources and sinks for nitrous oxide, Nature, 275, 602-606, 1978.

Farías, L., Paulmier, A., and Gallegos, M.: Nitrous oxide and $\mathrm{N}$-nutrient cycling in the oxygen minimum zone off northern Chile, Deep-Sea Res. Part I, 54, 164-180, doi:10.1016/j.dsr.2006.11.003, 2007.

Farías, L., Castro-González, M., Cornejo, M., Charpentier, J., Faundez, J., Boontanon, N., and Yoshida, N.: Denitrification and nitrous oxide cycling within the upper oxycline of the eastern tropical South Pacific oxygen minimum zone, Limnol. Oceanogr., 54, 132-144, doi:10.4319/lo.2009.54.1.0132, 2009.

Frame, C. H. and Casciotti, K. L.: Biogeochemical controls and isotopic signatures of nitrous oxide production by a marine ammonia-oxidizing bacterium, Biogeosciences, 7, 2695-2709, doi:10.5194/bg-7-2695-2010, 2010.

Freing, A., Wallace, D. W. R., Tanhua, T., Walter, S., and Bange, H. W.: North Atlantic production of nitrous oxide in the context of changing atmospheric levels, Global Biogeochem. Cy., 23, GB4015, doi:10.1029/2009GB003472, 2009.

Freing, A., Wallace, D. W. R., and Bange, H. W.: Global oceanic production of nitrous oxide $\left(\mathrm{N}_{2} \mathrm{O}\right)$, Philos. T. R. Soc. B, 367, 1245-1255, doi:10.1098/rstb.2011.0360, 2012.

Friederich, G. E., Codispoti, L., Spinrad, R. W., Packard, T. T., and Glover, H. E.: NITROP-85 data report, updated edition April 1992, in: Technical Report No. 59, Bigelow Laboratory for Ocean Sciences, 1992.

Garcia, H. E., Locarnini, R. A., Boyer, T. P., and Antonov, J. I.: World Ocean Atlas 2009, Volume 4: Nutrients (phosphate, nitrate, silicate), NOAA Atlas NESDIS 71, US Government Printing Office, 2010a.

Garcia, H. E., Locarnini, R. A., Boyer, T. P., Antonov, J. I., Baranova, O.K., Zweng, M. M., and Johnson, D. R.: World Ocean Atlas 2009, Volume 3: Dissolved Oxygen, Apparent Oxygen Utilization, and Oxygen Saturation, NOAA Atlas NESDIS 70, US Government Printing Office, 2010b.

Goreau, T. J., Kaplan, W. A., Wofsy, S. C., McElroy, M. B., Valois, F. W., and Watson, S. W.: Production of $\mathrm{NO}_{2}^{-}$and $\mathrm{N}_{2} \mathrm{O}$ by nitrifying bacteria at reduced concentrations of oxygen, Appl. Environ. Microb., 40, 526-532, 1980.

Holland, E. A., Lee-Taylor, J., Nevison, C., and Sulzman, J.: Global $\mathrm{N}$ Cycle: Fluxes and $\mathrm{N}_{2} \mathrm{O}$ Mixing Ratios Originating from Human Activity. Data set. Available on-line: http://www.daac.ornl.gov from Oak Ridge National Laboratory Distributed Active Archive Center, Oak Ridge, Tennessee, USA, doi:10.3334/ORNLDAAC/797, 2005.

Jin, X. and Gruber, N.: Offsetting the radiative benefit of ocean iron fertilization by enhancing $\mathrm{N}_{2} \mathrm{O}$ emissions, Geophys. Res. Lett., 30, 2249, doi:10.1029/2003GL018458, 2003.

Kalvelage, T., Jensen, M. M., Contreras, S., Revsbech, N. P., Lam, P., Günter, M., LaRoche, J., Lavik, G., and Kuypers, M. M. M.: Oxygen sensitivity of anammox and coupled N-cycle processes in oxygen minimum zones, PLoS ONE, 6, e29299, doi:10.1371/journal.pone.0029299, 2011.

Kartal, B., Kuypers, M. M., Lavik, G., Schalk, J., Op den Camp, H. J. M., Jetten, M. S. M., and Strous, M.: Anammox bacteria disguised as denitrifiers: nitrate reduction to dinitrogen gas via nitrite and ammonium, Environ. Microbiol, 9, 635-642, doi:10.1111/j.1462-2920.2006.01183.x, 2007.

Keller, D. P., Oschlies, A., and Eby, M.: A new marine ecosystem model for the University of Victoria Earth System Climate Model, Geosci. Model Dev., 5, 1195-1220, doi:10.5194/gmd-51195-2012, 2012.

Key, R. M., Kozyr, A., Sabine, C. L., Lee, K., Wanninkhof, R., Bullister, J. L., Feely, R. A., Millero, F. J., Mordy, C., and Peng, T.-H.: A global ocean carbon climatology: Results from Global Data Analysis Project (GLODAP), Global Biogeochem. Cy., 18, GB4031, doi:200410.1029/2004GB002247, 2004.

Körner, H. and Zumft, W. G.: Expression of denitrification enzymes in response to the dissolved oxygen level and respiratory substrate in continuous culture of Pseudomonas stutzeri, Appl. Environ. Microbiol., 55, 1670-1676, 1989.

Knowles, R., Lean, D. R. S., and Chan, Y. K.: Nitrous oxide concentrations in lakes: variations with depth and time, Limnol. Oceanogr., 26, 855-866, 1981.

Lam, P., Jensen, M. M., Kock, A., Lettmann, K. A., Plancherel, Y., Lavik, G., Bange, H. W., and Kuypers, M. M. M.: Origin and fate of the secondary nitrite maximum in the Arabian Sea, Biogeosciences, 8, 1565-1577, doi:10.5194/bg-8-1565-2011, 2011.

Large, W. G. and Yeager, S. G.: Diurnal to decadal global forcing for ocean and sea-ice models: The data sets and flux climatologies, Technical Report TN-460+STR, NCAR, 105pp., 2004.

Liu, W. T., Tang, W., and Polito, P. S.: NASA scatterometer provides global ocean-surface wind fields with more structures than numerical weather prediction, Geophys. Res. Lett., 25, 761-764, doi:10.1029/98GL00544, 1998.

Locarnini, R. A., Mishonov, A. V., Antonov, J. I., Boyer, T. P., and Garcia, H. E.: World Ocean Atlas 2009, Volume 1: Temperature, NOAA Atlas NESDIS 68, US Government Printing Office, 2010.

Löscher, C. R., Kock, A., Könneke, M., LaRoche, J., Bange, H. W., and Schmitz, R. A. A.: Production of oceanic nitrous oxide by ammonia-oxidizing archaea, Biogeosciences, 9, 2419-2429, doi:10.5194/bg-9-2419-2012, 2012.

Mckenney, D. J., Drury, C. F., Findlay, W. I., Mutus, B., McDonnell, T., and Gajda, C.: Kinetics of denitrification by Pseudomonas fluorescens: Oxygen effects, Soil Biol. Biochem., 26, 901-908, doi:10.1016/0038-0717(94)90306-9, 1994.

Montes, I., Colas, F., Capet, X., and Schneider, W.: On the pathways of the equatorial subsurface currents in the eastern equatorial $\mathrm{Pa}$ cific and their contributions to the Peru-Chile Undercurrent, J. Geophys. Res., 115, C09003, doi:201010.1029/2009JC005710, 2010.

Montes, I., Schneider, W., Colas, F., Blanke, B., and Echevin, V.: Subsurface connections in the eastern tropical Pacific during La Niña 1999-2001 and El Niño 2002-2003, J. Geophys. Res., 116, C12022, doi:201110.1029/2011JC007624, 2011.

Morrison, J. M., Codispoti, L., Gaurin, S., Jones, B., Manghnani, V., and Zheng, Z.: Seasonal variation of hydrographic and nutrient fields during the US JGOFS Arabian Sea process study, DeepSea Res. Part II, 45, 1903-1931, 1998.

Naqvi, S. W. A., Bange, H. W., Farías, L., Monteiro, P. M. S., Scranton M. I., and Zhang, J.: Marine hypoxia/anoxia as a source of 
$\mathrm{CH}_{4}$ and $\mathrm{N}_{2} \mathrm{O}$, Biogeosciences, 7, 2159-2190, doi:10.5194/bg7-2159-2010, 2010.

Nevison, C., Butler, J. H., and Elkins, J. W.: Global distribution of $\mathrm{N}_{2} \mathrm{O}$ and the $\Delta \mathrm{N}_{2} \mathrm{O}-\mathrm{AOU}$ yield in the subsurface ocean, Global Biogeochem. Cy., 17, 1119, doi:10.1029/2003GB002068, 2003.

Nicholls, J. C., Davies, C. A., and Trimmer, M.: High-resolution profiles and nitrogen isotope tracing reveal a dominant source of nitrous oxide and multiple pathways of nitrogen gas formation in the central Arabian Sea, Limnol. Oceanogr., 52, 156-168, 2007.

Payne, W. J., Riley, P. S., and Cox Jr., C. D.: Separate nitrite, nitric oxide, and nitrous oxide reducing fractions from Pseudomonas perfectomarinus, J. Bacteriol, 106, 356-361, 1971.

Peacock, S. and Maltrud, M.: Transit-Time Distributions in a Global Ocean Model, J. Phys. Oceanogr., 36, 474-495, 2005.

Pierotti, D. and Rasmussen, R. A.: Nitrous oxide measurements in the eastern tropical Pacific Ocean, Tellus, 32, 56-72, 1980.

Pizarro, O., Shaffer, G., Dewitte, B., and Ramos, M.: Dynamics of seasonal and interannual variability of the Peru-Chile Undercurrent, Geophys. Res. Lett., 29, 1581, doi:200210.1029/2002GL014790, 2002.

Popp, B. N., Westley, M. B., Toyoda, S., Miwa, T., Dore, J. E., Yoshida, N., Rust, T. M., Sansone, F. J., Russ, M. E., Ostrom, N. E., and Ostrom, P. H.: Nitrogen and oxygen isotopomeric constraints on the origins and sea-to-air flux of $\mathrm{N}_{2} \mathrm{O}$ in the oligotrophic subtropical North Pacific gyre, Global Biogeochem. Cy., 16, 1064, doi:200210.1029/2001GB001806, 2002.

Punshon, S. and Moore, R. M.: Nitrous oxide production and consumption in a eutrophic coastal embayment, Mar. Chem., 91, 3751, doi:10.1016/j.marchem.2004.04.003, 2004.

Ryabenko, E.: Nitrogen isotopes in the Atlantic and Pacific oxygen minimum zones, Ph.D. thesis, Christian-Albrechts-Universität zu Kiel, 2011.

Ryabenko, E., Kock, A., Bange, H. W., Altabet, M. A., and Wallace, D. W. R.: Contrasting biogeochemistry of nitrogen in the Atlantic and Pacific Oxygen Minimum Zones, Biogeosciences, 9, 203215, doi:10.5194/bg-9-203-2012, 2012.

Santoro, A. E., Buchwald, C., McIlvin, M. R., and Casciotti, K. L.: Isotopic signature of $\mathrm{N}_{2} \mathrm{O}$ produced by marine ammonia-oxidizing Archaea, Science, 333, 1282-1285, doi:10.1126/science.1208239, 2011.

Schmittner, A. and Galbraith, E.D.: Glacial greenhouse-gas fluctuations controlled by ocean circulation changes, Nature, 456, 373376, doi:10.1038/nature07531, 2008.

Shaffer, G., Salinas, S., Pizarro, O., Vega, A., and Hormazabal, S.: Currents in the deep ocean off Chile $\left(30^{\circ} \mathrm{S}\right)$, Deep-Sea Res. Part I, 42, 425-436, doi:10.1016/0967-0637(95)99823-6, 1995.

Stark S., Jenkins, W. J., and Doney, S. C.: Deposition and recirculation of tritium in the North Pacific Ocean, J. Geophys. Res., 109, C06009, doi:10.1029/2003JC002150, 2004.

Stramma, L., Johnson, G. C., Sprintall, J., and Mohrholz, V.: Expanding oxygen-minimum zones in the tropical oceans, Science, 320, 655-658, doi:10.1126/science.1153847, 2008.

Strub, P. T., Mesias, J. M., and James, C.: Altimeter observations of the Peru-Chile countercurrent, Geophys. Res. Lett., 22, 211-214, doi:199510.1029/94GL02807, 1995.
Suntharalingam, P. and Sarmiento, J. L.: Factors governing the oceanic nitrous oxide distribution: Simulations with an ocean general circulation model, Global Biogeochem. Cy., 14, 429454, 2000.

Suntharalingam, P., Sarmiento, J. L., and Toggweiler, J. R.: Global significance of nitrous-oxide production and transport from oceanic low-oxygen zones: A modeling study, Global Biogeochem. Cy., 14, 1353-1370, doi:10.1029/1999GB900100, 2000.

Suntharalingam, P., Buitenhuis, E., Quéré, C. L., Dentener, F., Nevison, C., Butler, J. H., Bange, H. W., and Forster, G.: Quantifying the impact of anthropogenic nitrogen deposition on oceanic nitrous oxide, Geophys. Res. Lett., 39, L07605, doi:201210.1029/2011GL050778, 2012.

Unterweger, M. P., Coursey, B. M., Schima, F. J., and Mann, W. B.: Preparation and calibration of the 1978 National Bureau of Standards tritiated water standards, Int. J. Appl. Radiat. Is., 31, 611-614, 1980.

Walker, S. J., Weiss, R. F., and Salameh, P. K.: Reconstructed histories of the annual mean atmospheric mole fractions for the halocarbons CFC-11 CFC-12, CFC-113, and carbon tetrachloride. J. Geophys. Res., 105, 14285-14296, doi:10.1029/1999JC900273, 2000.

Ward, B. B.: Nitrification in Marine Systems, in: Nitrogen in the Marine Environment, edited by: Capone, D. G., Bronk, D. A., Mulholland, M. R., and Carpenter, E. J., 199-261, Elsevier, Amsterdam, 2008.

Warner, M. J. and Weiss, R. F.: Solubilities of chlorofluorocarbons 11 and 12 in water and seawater, Deep-Sea Res., 32, 1485-1497, 1985.

Waugh, D. W., Hall, T. M., and Haine, T. W. N.: Relationships among tracer ages, J. Geophys. Res., 108, 3138, doi:200310.1029/2002JC001325, 2003.

Weiss, R. F. and Price, B. A.: Nitrous oxide solubility in water and seawater, Mar. Chem., 8, 347-359, 1980.

Wyrtki, K.: The horizontal and vertical field of motion in the Peru Current, Bull. Scripps Inst. Oceanogr., 8, 313-346, 1963.

Yamagishi, H., Westley, M. B., Popp, B. N., Toyoda, S., Yoshida, N., Watanabe, S., Koba, K., and Yamanaka, Y.: Role of nitrification and denitrification on the nitrous oxide cycle in the eastern tropical North Pacific and Gulf of California, J. Geophys. Res., 112, G02015, doi:10.1029/2006JG000227, 2007.

Yoshida, N., Morimoto, H., Hirano, M., Koike, I., Matsuo, S., Wada, E., Saino, T., and Hattori, A.: Nitrification rates and ${ }^{15} \mathrm{~N}$ abundances of $\mathrm{N}_{2} \mathrm{O}$ and $\mathrm{NO}_{3}^{-}$in the western North Pacific, Nature, 342, 895-897, doi:10.1038/342895a0, 1989.

Yoshinari, T.: Nitrous oxide in the sea, Mar. Chem., 4, 189-202, doi:10.1016/0304-4203(76)90007-4, 1976.

Zamora, L. M., Landolfi, A., Oschlies, A., Hansell, D. A., Dietze, H., and Dentener, F.: Atmospheric deposition of nutrients and excess $\mathrm{N}$ formation in the North Atlantic, Biogeosciences, 7, 777793, doi:10.5194/bg-7-777-2010, 2010.

Zumft, W. G.: Cell biology and molecular basis of denitrification, Microbiol. Mol. Biol. Rev., 61, 533-616, 1997. 